\title{
How Does the Choice of the Gender Indicator Affect the Analysis of Gender Differences in Agricultural Productivity? Evidence from Uganda
}

\author{
Authors: \\ Name: Ana Paula \\ Last Name: de la O Campos* \\ ${ }^{*}$ Corresponding author \\ The Food and Agriculture Organization of the United Nations \\ anapaula.delaocampos@fao.org \\ Palazzo della FAO \\ Viale delle Terme di Caracalla s/n \\ CAP 00152 \\ Rome, Italy \\ Ph: +3906570 56797 \\ Fax: +390657055522 \\ Name: Katia Alejandra \\ Last Name: Covarrubias \\ Graduate Institute of International and Development Studies, Geneva \\ katia.covarrubias@graduateinstitute.ch \\ Case postale 136, 1211 Geneva 21 \\ Ph: +4176 6750689 \\ Name: Alberto \\ Last Name: Prieto Patron \\ Independent Consultant \\ albertoprietopatron@gmail.com \\ Alberto.PrietoPatron@rdls.nestle.com
}




\section{Abstract}

We use OLS and decomposition techniques to investigate gender differences in agricultural productivity in Uganda. Using nationally representative surveys from years 2009-2012, the analysis applies different gender dummies - female head of household, female plot holder and female plot manager- to investigate how the variable of choice affects the calculation of the gender gap. Our analysis obtains different results depending on the gender variable of choice. The study finds that regardless of the variable of choice, the gender gap in agricultural productivity decreases or disappears when factors of production and crop choice are controlled for. The conditional gender gap is about 10 percent and significant when using female plot manager as the gender variable, while we find no conditional gender gap when using the other gender variables. The use of time fixed-effects and decomposition contributes evidence that the typically available gender variables are insufficient for identifying how gender and decision-making of different household members play a role in productivity. This finding is problematic for targeting effective interventions to increase agricultural productivity and reduce gender inequalities in agriculture. Finally, we find that the older status of female heads, holders and manager of plots, child dependency ratio and limited access to adult male labor are factors decreasing productivity in female plots in Uganda.

Key words: agricultural productivity, gender differential, gender variable, decomposition, Uganda JEL Codes: C21, J16, O13, Q12, Q18

\section{Acknowledgements}

This paper was prepared as part of a research initiative led by the World Bank LSMS Research Programme entitled "Gender Differentials in Agricultural Productivity: Identifying Opportunities for Agricultural Growth in Sub-Saharan Africa." The research initiative was funded by the World Bank LSMS, the Gates Foundation, International Fund for Agricultural Development, and the Food and Agriculture Organization of the United Nations. The authors are most grateful for the valuable feedback from numerous colleagues. In particular, the authors wish to thank three anonymous reviewers, Paul Winters, Talip Kilic, Silvio Daidone, Andre Croppenstedt and Susan Kaaria as well as the participants of the Gender and Agricultural Productivity in sub-Saharan Africa workshop at 
IFAD Headquarters in Rome, Italy. The findings, interpretations, and conclusions expressed in this work do not necessarily reflect the views of the FAO. Any errors and omissions are those of the authors.

\section{Introduction}

The Food and Agriculture Organization stated in its report on Women in Agriculture that the productivity of female farmers is often hampered by their limited access to productive resources and opportunities. The conclusion came after a substantial review of 27 studies on gender differentials in agricultural productivity that showed in most cases male farmers obtain higher productivity than female farmers (FAO, 2011). The studies choose different gender indicators to measure the gender gap in agricultural productivity, ranging from the sex of the household head to the sex of plot manager and the sex of the parcel owner, rendering problematic comparisons across studies and creating confusion on the gender-related aspects that matter to increase agricultural productivity (Quisumbing, 1996; Peterman et al., 2010).

The first objective of this paper is to contribute to the bulk of evidence on gender differentials in agricultural productivity by analyzing data from Uganda using OLS regression and decomposition techniques. Capitalizing on a new generation of datasets from the Living Standards Measurement Survey-Integrated Surveys in Agriculture (LSMS-ISA) Project of the World Bank, we use three waves of the Uganda National Panel Survey (UNPS), which provide highly detailed information on agricultural production at the plot level and information on men and women's roles in household agricultural production. We account for a wide set of observable variables available in the dataset using a standard Cobb-Douglas production function which is also the basis of the decomposition technique.

The second objective of the paper is to shed light on the usefulness of the gender variables in capturing household decision-making in agriculture. We test the extent to which the use of different gender variables changes the estimation of the gender gap in agricultural productivity, providing that the different gender variables are associated with different gender-related aspects as well as decision-making affecting agricultural production. The gender variables used in the study include female head of household, female plot holder, and female plot manager. We use decomposition techniques for 
deepening our understanding about the role of different gender variables in changing the endowment effect vis-à-vis their returns in explaining the gender differential in agricultural productivity.

Uganda is an interesting country for the study because its economy relies heavily on agriculture, with 65 percent of its population engaged in the sector, employing a higher share of women laborers. The sector relies mainly on smallholder agriculture, which has low access to technology and agricultural implements. In this context, the land tenure security of women continues to be hampered by the country's legal framework and legal pluralism, preventing women from inheriting land from their fathers and spouses, as well as accessing land titles. Increasing male and female farmers' productivity in agriculture is necessary for the country's current challenges of feeding an increasing population and facing climate change risks. Among the country's objectives for raising rural household's incomes and improving the food security and nutrition of all Ugandans, Uganda's Agriculture Sector Development Strategy and Investment Plan (DSIP) will seek to increase agricultural production and productivity. It is therefore necessary to further inform how gender inequalities are associated with lower productivity.

The rest of the paper is structured as follows. Section one reviews previous studies on gender differentials in agricultural productivity while section two provides the national context. Section three explains the characteristics of the data utilized and the construction of the gender variables. Section four explains the analytical framework and methods used. Section five presents the study results and section six is the discussion of results and the conclusion.

I. Gender differentials in Productivity and the Gender Variable of Choice The bulk of the available studies on gender differentials in agricultural productivity suggest that a gender gap persists in most cases, women achieving lower yields than men (FAO, 2011; Croppenstedt et al., 2013). The studies available for Sub-Saharan Africa show a gender gap ranging widely from 4 to 40 percent, the majority clustering around 20-30 percent (FAO, 2011; Kilic et al., 2013). A number of these studies estimate that the gender difference in productivity becomes insignificant when access to productive resources and individual characteristics are controlled for. Most of the available studies explain the gap by gender inequalities in endowments: women's lack of access to land and agricultural inputs, 
lack of tenure security, constraints in their ability to invest in land and improved technologies, less access to markets, credit, and human capital, and women facing more institutional constraints (e.g. discrimination), all which affect farm/plot management and the marketing of agricultural produce (Udry et al., 1995; Quisumbing, 1996; Tiruneh et al., 2001; Horrell and Krishnan, 2007). Recent studies have used decomposition techniques to also identify the effect of the returns to endowments, or the structure, in the gender productivity gap (Kilic et al., 2013; Aguilar et al., 2014; Oseni et al., 2014), showing in some cases more than 50 percent of the gap is unexplained. Therefore, the main conclusion from these studies is that females are equally efficient as male farmers, male-female differences not being determined by biological differences, but by gender differences in endowments and returns to endowments that arise from the socially constructed relationship between men and women (Oakley, 1972; Quisumbing, 1996; Peterman et al., 2010).

Different methodological approaches for measuring the gap, specifically when running the analysis either at the household or plot level lead to different measures and interpretations of the gender gap. Studies at the household level, which use the sex of the household head as the gender indicator, analyze the gender differences in market conditions and imperfections faced by the household as a whole, as well as the vulnerabilities associated to female headship, rendering difficult to account for female farmers' specific constraints in their plots. The bulk of evidence from this strand of the literature for Sub-Saharan Africa is mixed, finding female-headed households' productivity both lower and not significantly different from that of male-headed households. For example, the study of Tiruneh et al. (2001) in Ethiopia finds femaleheaded households having lower value of output per hectare than male-headed households, a 24 percent productivity disadvantage, while Chavas et al. (2005) do not find significant productivity differences by gender of the household head in Gambia after controlling for other inputs.

Peterman et al. (2010) argue that the nuances of different typologies of households lead to mixed results. Indeed, productivity differences between male and female-headed households may hide the resulting disadvantages of women's de jure headship vis-à-vis women's de facto headship, which differ in endowments and structural constraints. Few studies look at these nuances: Horrell and Krishnan (2007) find in Zimbabwe lower yields in poorer de jure female-headed households (e.g. households with 
widowed, separated or divorced female heads) as opposed to de facto female-headed households (e.g. wives of male migrants) with similar incomes to male-headed households.

Using the household head as the gender variable of choice is also problematic because the variable is not indicative of who makes decisions in agriculture or who owns land, crops or trees (Doss, 2001), creating more confusion for policy-making and targeting responses. Its use either assumes that only the characteristics of the household head influence household decisions or that all decision-makers in the household have the same preferences (Kleinjans, 2013). A great number of studies in agriculture still run gender analyses at the household level because of lack of adequate data.

Nevertheless, while still useful to analyze differences based on household typology -namely male, female, widowed, single-headed households- progress is under way to build more evidence at the plot level, where management decisions by gender are better captured. Within the last two decades, several studies have shown that intra-household decision-making on the allocation of resources within the household (land, inputs, water irrigation systems, and so on) is not Pareto-efficient (Udry, 1996; Quisumbing and Maluccio., 2003). Gender dynamics are relevant in this matter because decision-making in agricultural production, including what crops to plant and what inputs to use, are partly based on men and women's different entitlements and bargaining power (Agarwal, 2003; Goldstein and Udry, 2008), and particularly in the West-African context where female and male household members work and manage different family plots (Udry, 1996). Therefore, the transfer and adoption of agricultural technologies depends on these intra-household decisions (Tiruneh et al., 2001).

In their studies on gender differentials, Boserup (1970), Udry et al. (1995); Quisumbing (1996) find the gender gap in productivity is identified by the magnitude and statistical significance of the regression coefficient associated with the gender of, usually, the plot manager. ${ }^{1}$ This approach has been used since in numerous studies on productivity in Sub-Saharan Africa, the majority using regional or program-level data, and most recently, nationally-representative data (Aguilar et al. (2014), Akresh (2005), Alene et al. (2008), Gilbert et al. (2002), Goldstein and Udry (2008), Kilic et al. (2013), Oladeebo and Fajuyigbe (2007), Oseni et al. (2014), Peterman et al. (2010), Quisumbing et al. (2001) and Vargas Hill and Vigneri

\footnotetext{
${ }^{1}$ An additional advantage of plot-level analysis is more degrees of freedom (Quisumbing, 1996).
} 
(2011)). The bulk of these studies finds, in most cases, female plots are less productive than male plots. Udry et al. (1995) and Udry (1996) find that within the same household, women's yields were 19 percent lower than the yields of men in Burkina Faso. Akresh (2005) confirms these results for the same area in the country, but that gender differentials vary by region. Among the nationally-representative studies in Sub-Saharan Africa, gender differences with a male bias remain. Aguilar et al. (2014) find a 23.4 percent gender difference in productivity favoring men in Ethiopia; Kilic et al. (2013) find women's plots 25 percent less productive in Malawi, and Oseni et al. (2014) find that women produce 28 percent less than men in Northern Nigeria but observe no significant gender differences in Southern Nigeria. These studies also find that the structural effect of the gender gap, the part not explained by the endowment effect, accounts for a significant share of the gap.

The gender variable of choice also varies across the studies at plot-level. Besides the gender of the plot manager, the plot holder and plot owner are also used as the variable of choice. The latter is the least common approach (Goldstein and Udry, 2008; Peterman et al., 2010), probably a result of less available sex-disaggregated data on land ownership. The implications of using the plot holder versus the plot owner as the gender variable of choice have not been widely studied for the same country-dataset. The concepts of management, holding and ownership may be understood by survey respondents in the same way in some contexts but different in others, depending on the existing tenure systems. The responsibilities in production may also vary according to these definitions.

Finally, the effects in productivity captured by intra-household dynamics in plots co-managed or co-owned have not been analyzed widely either, particularly in East African settings where these types of plot-level arrangements constitute a significant share as opposed to West African setting of individual plot management. We find two studies, Peterman et al. (2010) and (Kilic et al., 2013) that look at the differences in productivity when plots are co-owned and co-managed by a man and a woman in Uganda and Malawi respectively. While the study in Malawi finds comparable gender gaps when using the overall sample and a sub-sample of plots co-managed by men and women, the study in Uganda finds that mixed-plot ownership captured the impact of unobserved household characteristics when not controlling for household-fixed effects. 
As gender inequalities in agriculture are recurrent and recognized as a major area for policy action, gender analysis should be able to identify what aspects in intra-household dynamics, including decision making in agriculture, increase or decrease agricultural productivity. In this context, the choice of the gender variable, as well as the level of disaggregation of the data in agricultural productivity analysis, is of great relevance.

\section{Uganda}

Uganda is a low-income country with a current GDP of US $\$ 21.49$ billion, where the agricultural sector contributes $24.5 \%$ to total GDP. Its economy has been on the rise since the end of the civil conflict in 1986 at an average range of 5-6 percent, although in 2012 the rate decreased to 3.4 percent. Uganda's population in 2013 was 37.58 million, of which 85 percent lived in rural areas. The country has seen great progress in poverty reduction from a poverty headcount ratio of US $\$ 2$ a day of 86 percent in 1989 down to 62.9 percent in 2013 , and from a poverty headcount ratio of US $\$ 1.25$ day of 69 percent down to 37.8 percent in the same years (WDI, 2015). However, poverty in rural areas remains high and households engaged in agriculture are the poorest (Mukwaya et al., 2011).

The agricultural sector is the greatest employer in Uganda as 65.6 percent of the population was engaged in the sector in 2009. In 2004, agriculture employed 76 percent of all women and 62 percent of all men (WDI, 2015). In smallholder farming, men have the role of land clearing while women are responsible for weeding and post-harvest processing (Kasente et al., 2002). Also, plantains and tubers, are considered "female crops" while cash crops (e.g. coffee and tobacco) are considered "male crops" (Kasente et al., 2002); however, traditional gender divisions of labor can vary widely across regions and socioeconomic status. In households headed by women and in some polygamous households, women perform tasks traditionally done by men (Howard and Nabanoga, 2007).

Crop production has increased since the 1980's as did the share of permanent crop land area, which was 11 percent in 2011; however the level of agricultural input use remains low. This means that increases in crop production over the past several decades have been obtained mainly through expansion of cropped area rather than improved yields on existing cropped land (Mukwaya et al., 2011). 
Despite low yields for main crops, agricultural potential is described to be high, given the country's agroecological diversity (McDonagh and Bahiigwa, 2002). One of the most prominent barriers to increased agricultural activity in Uganda is the lack of financial capital to purchase land and inputs (seeds, fertilizer, pesticides) or to hire labor when needed (Dolan, 2002). In addition, in traditional societies, such as the Baganda communities (Howard and Nabanoga, 2007), cultural practices related to land dictate that women can access land through their male relatives, such as a father, husband or brother, but in most communities they cannot own land and the husband owns the crops cultivated by women (FAO, 2015). They can plough the land to produce food crops, but they may not plant perennial crops, sell the land or use it as collateral without permission from men.

According to Doss et al. (2013), of the total land area owned by households in Uganda, women own 18\% solely, or $48 \%$ jointly with men. Women's land rights and tenure security in Uganda are harmed by legal pluralism and disadvantages created for women in inheritance and land-related laws. The Succession Act, effective since 1964, still legitimizes the devolution of the residential holding to the oldest male descendant, leaving the wife and wives of a male intestate with only 15 percent of his estate, while lineal descendants receive 75 percent. Moreover, a widow loses her residential holding upon remarriage, losing her right to cultivate, farm or till any land adjoining the residential holding (FAO, 2015).

\section{Data}

\section{(i) Uganda National Panel Survey}

The study uses data from the Uganda National Panel Survey (UNPS), a multi-topic panel survey carried out annually over a 12-month period on a nationally representative sample of households. Our main analysis uses the second wave - conducted between November 2010 to October 2011- and the third, most recent wave - conducted between November 2011 and November 2012. Both surveys were implemented by the Uganda Bureau of Statistics with the support of the World Bank Living Standards Measurement Study-Integrated Surveys on Agriculture (LSMS-ISA) project. In addition, we also use the 2009-10 wave to include lagged variables for one component of the analysis.

The data was collected within a two-stage cluster sampling design and is representative at the national, urban-rural, regional and main regional levels (North, East, West and Central regions), covering 2,716 
households in 753 enumeration areas in both waves. The UNPS is a multi-purpose survey consisting of five questionnaires, including household, women, community, market, and agriculture questionnaires. The agricultural questionnaire data is the basis of our analysis and collects information necessary for productivity analysis at the parcel and plot levels. The purpose of the agricultural questionnaire is to provide a better picture of Uganda's farm economy and a deeper insight into factors affecting farming incomes. Therefore, the data includes land characteristics, parcel area, quantification of agricultural production at parcel-plot-crop levels, ${ }^{2}$ agricultural inputs including fertilizers and pesticides, family and hired labor input, livestock expenditure and income, livestock products, access to extension services, and farm implements, among others. The survey was conducted in two visits, six months apart to better capture agricultural outcomes associated with the two cropping seasons of the country (UBS, 2011). We obtain a final sample of 6,798 plots from the second wave (2010/11) and a panel of 5,497 plots in both rounds (2010/11 and 2011/12). ${ }^{3}$

\section{(ii) Construction of gender variables}

In addition to the gender of the head of household, ${ }^{4}$ we draw upon questions of the survey recording the two principal parcel holders (either owners or individuals with use rights over the land), as well as parcel managers, to construct the gender variables of the study. We assign all plots belonging to one parcel to the member identified by the questions above. This is a reliable strategy as the average number of plots per parcel is about 1.89. We control for land ownership with a dummy on ownership throughout the analysis. ${ }^{5}$ The roster ID of the reported household members allowed linking each plot with individual characteristics including the sex, education, marital status, and so forth. This wealth of data allows us to construct different gender variables that, along with the sex of the household head, will constitute the basis of our study. The questions used are the following:

\footnotetext{
${ }^{2}$ Crop cards were used to better quantify the production of continuously harvested as well as staple crops.

${ }^{3}$ We excluded from the analysis plots that were left fallow, were used for pasture, or belong to woodlot and forests, which account for less than $2 \%$ of the overall sample.

${ }^{4}$ The data we use does not allow us to identify de facto female-headed households by not including information on migration of the spouse.

${ }^{5}$ We also ran the overall analysis using plot owner as gender variable of choice using the subsample of plots that are reported as owned, with or without documentation. We do not include these results here because they are similar to those using the plot holder. The results are available upon request to the authors.
} 
(1) "Who has the ownership/use rights of this parcel?" (The survey separates between those plots owned and those in which the reported individual have use rights, such as in renting).

(2) "Who manages/controls the output from this parcel among household members?"

Using this information, we create plot samples based on the gender of the holder and manager of output reported. For simplicity, in the text we refer to female-held plots and female-managed plots to plots that are respectively held/managed by women only. Conversely, we will refer as male-held plots and malemanaged plots to plots held/managed by males only; and jointly-held and jointly-managed plots to plots held/managed by a man and a woman. The joint-plot approach assumes that men and women allocate the same inputs and labor to the plot. However, we recognize that the assumption discounts potential agricultural decision-making conflict due to male/female bargaining power imbalances that go unobserved in the data. The use of year fixed effects allows us to address any resulting bias by accounting for the time invariant component of such imbalances, while district fixed effects capture cultural and social sources of those power imbalances given the spatial clustering of ethnic groups in Uganda. We observe 104 districts in our sample of Uganda, which is considerably detailed given that 56 legally recognized ethnic groups are documented to exist in the country (UBOS, 2002).

\section{(iii) Descriptive statistics}

Table 1 shows descriptive statistics of the 2010/11 round across three different plot samples based on the gender variables of choice. T-tests of the difference in means are run based on the male household head, and joint plot categories respectively. Results show that most of the female-held plots (92 percent) belong to female-headed households. Similarly, plots managed by women also belong to female-headed households (77 percent) but in a lower proportion. Therefore, at first glance, the gender variables presented here may not behave very different for Uganda, particularly between samples based on the gender of the head and holder. Nevertheless, differences in gender variables may be more significant for other countries according to their different tenure systems, as well as who can access or has right to use/own land. It is important to note, however, that the gender variable overlap only concerns the first reported individual. Therefore, the individual characteristics of the female head of household and the first reported female holder are similar, particularly those related to age, years of schooling and marital status, 
while those belonging to female managers are on average different across these characteristics. Also, plots belonging to female managers have a lower probability of belonging to female-headed households, and probably as a result, to wealthier households and access to a different bundle of assets, labor and inputs. Conversely, we can also assume that female-managed plots face more conflict in the allocation of intra-household resources and labor.

In terms of other characteristics, all female plots are smaller in size; however, they show a greater prevalence of irrigation, even though this technology is not widespread in Uganda. Plots held and managed by females have more insecure tenure (fewer titles). Female plots have less access to family male labor and use more family child labor; although they receive more overall family labor input (days worked). They also use fewer pesticides, receive less technical assistance, and grow more sweet potatoes.

[Table 1 here]

Female plots show lower average production than male plots, but no difference in overall average productivity. However, testing the difference in the distribution of productivity across gender reveals significant differences when comparing productivity on female plots against that on plots of male or joint gender. Figure 1 show the distribution of our dependent variable, a productivity measure generated by the value of production per acre for both seasons in 2010/11, disaggregated by the three gender variables. ${ }^{6}$ The distributions show subtle gender differences in all gender variable specifications, with male productivity distribution skewed to the right of the graph and peaking higher than the female distribution. Two-sample Kolmorogov-Smirnov tests for the equality of the distributions demonstrate that the female distributions are significantly different ${ }^{7}$ when compared to the other distributions (male and joint) under all three definitions of gender.

[Figure 1 here]

\footnotetext{
${ }^{6}$ Production is quantified using a standardized set of median crop prices estimated from the self-reported information on crop sales values. Median prices are compounded at an EA (enumeration area) basis. If less than 10 observations for a given product at a given EA are obtained, the price is estimated at the next geographical level in terms of aggregation.

${ }^{7}$ In the comparison of female versus male and female versus joint for holders, owners and managers, we reject the null hypothesis that the distributions are equal in all cases at the $95 \%$ and greater confidence level.
} 


\section{Framework and Methods}

The analysis follows a similar approach to Aguilar et al. (2014), Kilic et al. (2013) and Oseni et al. (2014) who respectively use data from Ethiopia, Malawi, and Nigeria to measure the gender gap in productivity. These studies use the sex of plot manager (for Malawi and Nigeria) and the sex of parcel manger (for Ethiopia) to estimate the gender gap. Our analysis consists of sets of pooled and separate sample regressions for each type of male and female plots according to the gender variable of choice. These regressions provide the basis for the decomposition methods. The empirical approach is explained in more detail below.

\section{(i) Gender differentials in agricultural productivity}

Our model begins by conceiving agricultural productivity as a standard production function of assets and inputs, namely land, agricultural capital, labor, fertilizer and pesticides. Recognizing that a broader set of factors is likely to influence production outcomes in the context of a non-unitary household model and our hypothesis of gender-differentiated agricultural decision-making, the function is also conditional on a series of plot and household-specific characteristics that are likely to affect the level of output through technology, wealth, skills and knowledge.

Our analysis starts with a basic pooled regression of:

$\ln Y_{i j k t}=\alpha_{0}+\alpha_{1} T_{i j k t}+\alpha_{2} C C_{i j k t}+\alpha_{3} X_{1 i j k t}+\gamma X_{2 k t}+\delta G_{j k t}+\varepsilon_{i j k t}$

for which $\ln Y$ is the natural logarithm of annual total gross value of crop production per acre on plot $i$ from parcel $j$ in household $k$ at time $t ; T$ is a vector of plot-level characteristics and inputs (ownership, log plot size, dummies for good quality of soil, flat slope of plot, irrigation, remoteness of the plot, fertilizer and pesticide use, and dummies for male, female and child family labor as well as hired labor); $C C$ represents plot-level crop production decisions (dummies for cultivating maize, beans, cassava, banana food, sweet potato and coffee, marketed production and the log area share of the plot cultivated with staples); $X_{1}$ is a vector of individual characteristics describing the gender variable of choice associated with the plot (age, years of schooling and civil status); $X_{2}$ is a vector of household characteristics that relate to family labor, 
skills and wealth (number of household adult members, child dependency ratio, dummy for any household member receiving technical assistance, and a household assets wealth index ${ }^{8}$ ); $G$ is the dummy variable for the sex of the gender variable of choice; and $\varepsilon$ is the error term. The respective factor coefficients are $\alpha, \gamma$. and $\delta$, with $\delta$ representing male-female differences in productivity.

The pooled regression results assume that the same technology is available to both male and female farmers (Quisumbing, 1996) and may ignore potential endogeneity resulting on household allocation of plots and crops to male, female and joint plots; therefore, we then run separate regressions of the female, joint and male samples according to the gender variables described in section (III.ii):

$\ln Y_{i j k t, F}=\alpha_{0}+\alpha_{1} T_{i j k t, F}+\alpha_{2} C C_{i j k t, F}+\beta X_{1 j k t, F}+\gamma X_{2 k t, F}+\varepsilon_{i j k t, F}$

$\ln Y_{i j k t, J}=\alpha_{0}+\alpha_{1} T_{i j k t, J}+\alpha_{2} C C_{i j k t, J}+\beta X_{1 j k t, J}+\gamma X_{2 k t, J}+\varepsilon_{i j k t, J}$

$\ln Y_{i j k t, M}=\alpha_{0}+\alpha_{1} T_{i j k t, M}+\alpha_{2} C C_{i j k t, M}+\beta X_{1 j k t, M}+\gamma X_{2 k t, M}+\varepsilon_{i j k t, M}$

where $\mathrm{F}, \mathrm{J}$, and $\mathrm{M}$ index the female, joint and male gender category of plot is holder, owner, manager or household head. The coefficients of equations (1-4) are the basis of our decomposition method, which is explained in the section (iii) below.

As described in Section II, substantial heterogeneity characterizes Uganda in terms of the economy, the environment and society. These differences can have effects on the level of production in terms of agricultural potential, but also in terms of access to markets, the interactions between farm and non-farm activities and the possibility to cultivate higher-value as opposed to staple goods. In terms of cultural norms, these also vary across the country and could have implications for the extent to which women are engaged in economic activities, are able to access and cultivate land, and have voice or decision-making power within households. For this reason, district level fixed effects are applied to all estimations in order to account for the factors of this nature that are invariant within districts and that could bear influence on

\footnotetext{
${ }^{8}$ The wealth index was constructed by principal components analysis and captures household access to agricultural machinery such as tractors, trailers, ploughs, and non-agricultural assets and services such as a house, buildings, non-agricultural land, furniture, electrical appliances, television, radio, generators, solar panels, bicycles, motorcycles, motor vehicles, boats, computer, mobile phones, internet. The resulting index is positively correlated with wealth.
} 
gendered productivity levels. Furthermore, adding precision to our inference, standard errors are clustered at the parcel level in order to account for correlation across plots situated in the same parcel. ${ }^{9}$

Whereas the fixed effects approach will allow us to remove the potential bias due to spatially-invariant unobservable characteristics, the possibility of simultaneity bias persists under the current specification, given that production and consumption decisions are unlikely to be taken separately. In fact, the largely subsistence nature of Ugandan agriculture indicates that non-separability is likely the case and that input use may be endogenous in the above specification. In order to test for this potential source of endogeneity, we probe whether results are robust to lagged input decisions, taking advantage of data available from the 2009-10 round of the UNPS. Results from this exploration are reported in section (V.i.3).

\section{(ii) Decomposition Methods}

The decomposition techniques of Oaxaca (1973) and Blinder (1973) are typically used to analyze wage inequalities across different population groups. In this paper, we apply them to the field of agricultural economics in order to compare differences in endowment and structural effects in productivity across the different gender variables described in the previous section. We estimate the gap between male and female plots (headed, held, managed) in agricultural productivity using the Oaxaca-Blinder regressionbased mean decomposition approach. The gender productivity gap, $D$, can be expressed as the difference in average outcomes between groups based on the linear estimation of the log of agricultural productivity using equations (1-4):

$D=E\left(\ln Y_{M}\right)-E\left(\ln Y_{F}\right)=E\left(X_{M}\right)^{\prime} \beta_{M}-E\left(X_{F}\right)^{\prime} \beta_{F}$

because

$E\left(\ln Y_{g}\right)=E\left(X_{g}^{\prime} \beta_{g}+\epsilon_{g}\right)=E\left(X_{g}^{\prime} \beta_{g}\right)+E\left(\epsilon_{g}\right)=E\left(X_{g}\right)^{\prime} \beta_{g}$

where $g \in\{F, M\}, \beta_{g}$ is inclusive of a constant term, $E\left(\beta_{g}\right)=\beta_{g}$ and $E\left(\epsilon_{g}\right)=0$ by assumption.

As described in detail by Kilic et al. (2013), from (5) we can obtain the aggregate decomposition equation: $D=$

\footnotetext{
${ }^{9}$ We don't use household fixed effects in our model due to limited variability of gender-plot typologies within households.
} 
Endowment Effect $=\left[E\left(X_{M}\right)-E\left(X_{F}\right)\right] \beta^{*}$

Male Structural Advantage $=E\left(X_{M}\right)\left(\beta_{M}-\beta^{*}\right)$

Female Structural Disadvantage $=E\left(X_{F}\right)\left(\beta_{F}-\beta^{*}\right)$

where $\beta^{*}$ represents the vector of coefficients estimated from the pooled regression of agricultural productivity and in which the gender variable of choice is identified (equation 1). The endowment effect represents the extent of the productivity gap that can be attributed to differences between male and female plots in terms of the observed covariates. Conversely, the structural effect describes the share of the gap that is sourced in unequal returns to the observed covariates. This effect is subdivided into the male advantage and female disadvantage, which are calculated based on the deviation of the respective group coefficients from the pooled estimates.

A number of criticisms characterize this decomposition approach and are summarized carefully by Fortin

et al. (2011). In particular, it is worth mentioning that the use of regression-based mean decomposition techniques requires a strong set of assumptions, among which a partial equilibrium framework is required. We apply the technique despite its shortcomings because it nonetheless allows us to document the relative quantitative importance of factors in explaining an observed gap. It is important to highlight that causality cannot be deduced from the estimated parameters. Instead correlations are observed as part of the relationships estimated. This does not, however, detract from the value of the analysis, which is essential for shedding greater light on how gender productivity differences are sensitive to the choice of gender indicator.

\section{Results}

\section{(i) Base Regressions Results}

\section{Base Pooled Regression}

An initial naïve regression using the gender variable as the sole regressor results of which are reported in columns (1), (5) and (10) of Table 2, shows a significant gender gap in productivity ranging from 15 to 19 percent. When applying equation (1), adding to the naïve specification covariates on individual and household characteristics, plot characteristics, inputs and crop choice, the gender gap loses its economic magnitude and significance for all the different gender variables except plot managers, where it remains 
significant at 95 percent confidence and of a magnitude of nearly 10 percent. In this respect, the gender variables used regarding household head and plot holder tell us very little on the effect of gender in agricultural productivity. In those cases, it is not the gender of the head, holder or manager per se, but the factors of production that increase productivity, notably plot size, the quality of the soil, the amount of hired labor and male family labor working in the plot, the use of agricultural inputs, and crop orientation

(table 2, columns (2), (6) and (11)). Conversely, the gender in terms of the plot manager does remain relevant, in addition to the aforementioned factors of production. This outcome reveals the nuanced nature of the lines along which gender is defined, and the sensitivity of results to such definition. Whereas household head and plot holder status do not seem to link directly to productivity-enhancing decisions, the gender of the plot manager may perhaps serve as a better approximation of the gender dimension of agricultural decision-making processes.

[table 2 here]

\section{Separate Gender-based Sample Regressions}

The separate gender-plot regressions, also in table 2, columns (3-4), (7-9) and (12-14), provide information about the different factors increasing or decreasing productivity in male, joint, and female plots. The results show that for heads, holders and managers on joint plots, age is positively associated with productivity (with a decreasing effect), whereas for female plots age has a negative association or is not significant. Although experience and know-how is increasing with age, and should therefore be positively associated with productivity, the "returns to age" are different across gender lines as women heads, holders and managers in Uganda are on average older than their male counterparts, which suggests a limited potential to work relative to men, as physical capacity is expected to diminish with age. A higher child dependency ratio within households also has a higher negative effect in female-headed plots, with a sizeable and significant coefficient at the 10 percent level. This result is not observed within male and joint plots, indicating that domestic care responsibilities, traditionally undertaken by women, may be constraining productivity of their plots. In fact, in Uganda, an important share of households headed by women is formed by older women (30.7 percent are over 60 years) or widows (45.5 percent), 
caring for small children due to the loss of parents to HIV-AIDS and to a greater extent than their male counterparts. ${ }^{10}$

Conversely, larger households with more adult members mean more labor is available for women's plots, contributing to increased productivity. This is suggested by the coefficient of "number of adult members in the household" which is significant at the 1 percent level for plots of female-headed households, and significant at the 10 percent level for female-held and female-managed plots. Since female plots tend to have fewer adult household members, the productivity gains from an additional adult are likely to be greater than for male plots, which come from households with a greater adult labor supply.

Although male-headed households show on average a higher child dependency ratio in the descriptive statistics, they also have more adult members that may supply childcare in the household. The issue of labor availability is further highlighted by the negative and significant relationship on female-held plots between the participation of any family member in non-agricultural wage labor and productivity. For these households, involvement in off-farm work draws upon an already small pool of adult labor, constraining productive capacity. This outcome is confirmed by the smaller economic size and lower or lack of significance of coefficients of male adult family labor used in female plots compared to joint plots, suggesting low access to this labor. Finally, the results show factors of inputs and crop choice having similar effects across joint and female plots.

\section{Sensitivity Analysis and Robustness Checks}

In order to test for the sensitivity of the base regression specification in equation (1), we run separate pooled regressions across five main crops in Uganda. Table 3 shows the resulting gender dummy covariates across the different crop-sample regressions. Only the conditional gender gap for sweet potato productivity is significant for both holder and manager models, which are about 22 and 21 percent respectively and significant at 5 percent level. Differences in sweet potato productivity across gender may reflect a number of other gendered constraints in terms of labor, inputs and skills, especially in light of the fact that a greater share of female plots produces this crop, yet they are seemingly less productive. This

\footnotetext{
10 Our sample indicates that widowed female heads live in households with a dependency ratio of 0.2 , which is approximately double of that of households headed by widowed males The widowed female household head dependency ratio is also 17 percent greater than the overall male headed sample
} 
observation suggests female farmers may be utilizing sweet potato production as a low-risk, low-return strategy. Apart from this finding, however, the results at the crop level suggest that the gender differential in productivity is not strongly linked to specific crops. If taking into consideration that crop choice does matter for overall productivity (see Table 2), it appears that the gender gap is relevant at the level of the entire portfolio, rather than for crop-specific yields. Finally, it is worth noting that even at the crop level factors of production such as labor and other inputs are important contributors to productivity, in line with our previous findings.

\section{[Table 3 here]}

Exploring the role of different groups of covariates through a step-wise approach allows us to learn how the gender gap is sensitive to the introduction of different covariates to the model and guides our understanding of which set of variables may drive or diminish the gender effect in the pooled regressions. Starting with the base set of gender and individual characteristics, additional covariates are added to the specification in groups corresponding with (1) household characteristics; (2) land descriptors; (3) labor input; (4) other inputs; (5) market-orientation; and (6) crop portfolio characteristics. Results presented in Table 4 demonstrate that for plot holders the gender differential is negative and significant, an effect that is robust to the introduction of household and plot characteristics to the specification. When labor supply is included in the specification, the gender variable loses significance. For plot managers, the negative effect of gender on productivity is also robust to labor supply variables; however, when other inputs such as fertilizer and pesticides are factored in, it also becomes insignificant. These findings demonstrate that productive inputs (labor, fertilizer, pesticides) supersede the role of other factors, including the sex of the head, holder or manager, in explaining gender productivity differentials.

In Uganda, the different extent to which the gender effect is captured by other covariates also highlights the sensitive nature of the gender definition. Whereas classifying gender in terms of plot holders versus managers reveals which covariates capture the gender differential, defining gender in terms of household heads leads the gender variable to become insignificant in all specifications.

[Table 4 here] 
A final specification check is implemented to account for the potentially simultaneous nature of input and output decisions on the farm that could confound the estimation results, as described in Section IV.i. Simultaneity is obviated by taking advantage of an earlier round of the UNPS, collected in 2009-10 in the same level of detail as the rounds analyzed in this paper. Lagged input decisions regarding fertilizer, pesticides, hired labor, and inter-cropping are incorporated to the analysis instead of the contemporaneous variables regarding these inputs. ${ }^{11}$ Table 5 reports results based on the estimation of equations (2-4) using the lagged input variables.

On the whole, results are substantially consistent with this adjustment to the specification; any changes are in line with expectations: fertilizer use and hired labor lose significance. However, the use of pesticides actually remains strongly significant over time; a finding that suggests pesticide use may have long-term effects on the soil, such that future production may benefit from the previous use of pesticides on the same parcel. In some cases, variables gain or lose marginal significance (years of schooling, polygamous married, land ownership, family labor) but these are isolated cases, which do not have an influence over the main findings.

Apart from these minor adjustments in the results due to the use of a lagged specification, the remaining set of results corresponds with the findings using all contemporaneous variables in such a way that our main conclusions are unaffected. In the next sub-section we take advantage of the subsequent round of the UNPS in order to implement another approach that captures unobservable time-specific factors in a more comprehensive manner than the simple use of lagged decision-making.

[Table 5 here]

(ii) Results with time fixed-effects

We re-run the base regressions (equations 1-4) applying year and district fixed-effects to the plot-level panel generated by linking the 2010/11 and 2011/12 UNPS rounds. The purpose of using year fixedeffects is to control for unobservable time-invariant characteristics that may influence productivity. At the

\footnotetext{
${ }^{11}$ In order to incorporate these variables, parcels are linked across rounds. Not all parcels from the 2009-10 survey were re-interviewed in the 2010-11 survey, leading to a smaller sample for this robustness check. We were able to analyze the 5,456 plots with non-missing data in both rounds.
} 
household level, such factors may relate to intra-household dynamics and gender power relations that determine resource allocation to male and female plots, as well as the allocation of plots in the first place. With only one year elapsing between rounds, we can assert that intra-household dynamics are likely to remain relatively constant, permitting the use of time fixed effects to capture such dynamics. In practice, very few household characteristics change over time (Table 6). All household head characteristics except age - which naturally increases over time - are statistically the same across rounds. At the household level, the dependency ratio decreases slightly, as can be expected since the increase in age of children will reduce the ratio of dependents to adults, while the slight decrease in participation in labor income may reflect the ageing of adult household members. A minor decrease in the years of schooling of the head could reflect some shift in the person heading the household, but given that all other household head characteristics do not change significantly over time, this shift could be attributed to a survey implementation issue such as measurement error.

[Table 6 here]

Table 7 shows the pooled and separate regressions using the head of household and plot holder as the gender variable of choice. ${ }^{12}$ In this round of results, the conditional gender gap changes sign but remains small and statistically insignificant. The effects of age are in line with expectations and confirm that productivity in female plots is affected by the older age of female heads of households and holders. Unmarried status of the male head of household or the holder is now associated with increased productivity. This result lends support to the hypothesis that male-female tensions play a role in the allocation of resources, and thus, in productivity. Household participation in non-agricultural wage labor is now positive and significant in the pooled regression, but remains negative and significant for female-held plots, highlighting the competition for household labor allocation faced by female plots that in turn constrains productivity.

Results confirm the inverse relationship of land size and productivity, as seen in the previous models. In this model, we observe also that the land size coefficient for female plots is much larger than that of male plots indicating that female plots are less productive when larger in size, suggesting labor capacity constraints in these plots. Such constraints are observed in the descriptive statistics, which demonstrate

\footnotetext{
${ }^{12}$ A similar analysis using the gender of plot manager is not possible because the 2011-12 survey does not ask households to identify plot managers using the same question, and therefore, definition of plot manager.
} 
female plots belong to household with fewer adult members and that they disproportionately rely on child and female, rather than male labor. If observed labor and input constraints are considered in conjunction with the significantly lower returns to land, as given in Table 7, we can infer that if female plots were as large as male plots, the gender gap in productivity would be probably larger, all things equal.

Distance to plot is now negative, sizeable, and significant at 5 percent level for plots headed by women, indicating that remoteness constrains productivity, probably as a result of constrained access to input, output and labor markets, and time-consuming household care responsibilities, which are at odds with production responsibilities.

This round of results confirms that hired labor is linked to increased productivity and that it serves as a substitute for male family labor on male and jointly managed plots, but not on female plots. The nonsignificance of hired labor for female plots indicates that hiring in labor does not impact productivity for female producers. This finding is not necessarily due to differences in access to hired labor markets; table 1 shows that an important share of male and female plots access hired labor. Instead, if this outcome is considered in conjunction with the overall input constraints faced by female producers, the nonsignificance of hired labor in productivity could be due to an intensity or quality constraint: female producers that hire-in may not hire-in enough labor to ensue productivity gains, or may not hire-in enough skilled labor to improve production. As a result, female farmers who hire labor may simply be as productive as other female farmers who rely primarily on female and child family labor.

The results further demonstrate that female family labor contributes to increased productivity on all plots, with significant gains for five of the seven specifications. Therefore, despite the so-called female "time poverty" trap, their labor contribution to production is fundamental, especially in view of other input constraints.

Use of fertilizers now loses size and statistical power, and in the separate regression for female plots, it loses significance, whereas the use of pesticides also loses statistical power but the point estimates remain stable. Technical assistance loses significance, indicating that time effects are capturing the increase in skills and know-how acquired by producers between rounds.

The outcomes observed by running the analysis using the plot-level panel provide evidence in line with the results obtained from the cross-sectional analysis, with the advantage that both time and spatially 
invariant unobservable factors are accounted for. Given that the model specification captures a broad range of observable factors that vary across those dimensions, these regressions provide a set of robust and unbiased results upon which to consider the role of gender in agricultural productivity.

[Table 7 here]

(iii) Decomposition Results

\section{Mean Gender Differential}

The Oaxaca decomposition results are shown in Table 8. The mean gender differential (panel A) shows a difference in mean log productivity between plots of male and female-headed households of 0.177 , equivalent to 19.4 percent. The productivity gap is higher when only male and only female plots are compared, at about 22 percent, significant at the 1 percent level. The mean gender differential is only significant at the 10 percent level and loses economic size when jointly-held versus female-held plots are compared, but remains relevant with a magnitude of 10.6 percent. In turn, it loses value and significance when jointly-managed and female-managed plots are compared. These results signal a greater difference in productivity between male-only and female-only plots than between joint and female-only plots.

\section{Aggregate Decomposition}

The results of the aggregate decomposition (panel B in table 8) show that 58 to 96 percent of the gender differential in productivity in Uganda is explained by the endowment effect to different degrees according to the gender variable of choice. The endowment effect is the part of the gender gap attributed to observed covariates that include, for example, the observed differences in the quantity of adult male labor and the in the use of agricultural inputs in female plots in relation to male and joint plots. The endowment effect is highest when comparing male and female-held plots (0.133), and lowest when comparing joint and female managed plots (0.042).

Conversely, the female structural advantage explains a smaller portion of the difference in productivity, from 4 up to 42 percent, being highest when comparing male and female-managed plots $(0.085)$, and lowest between joint and female-held plots (0.004). The female-plot structural disadvantage is the portion of the gender gap driven by the deviation of the female-plot return to the average return to covariates. This is observed, for example, in the returns that female plots obtain from the child dependency ratio and to adult male labor compared to male and joint plots. Finally, in all models, the male-plot structural 
advantage is minimal, suggesting that the factors affecting productivity on male plots do not diverge from the average.

The decomposition also demonstrates that production inequalities in Uganda's agricultural sector are a multi-level issue. First, female producers are mostly disadvantaged in terms of assets, labor and inputs (the endowment effect). They are further subject to differential returns in their endowment to those assets, labor and inputs (the structural effect). Table 8 provides evidence that the extent to which the gender gap can be explained by the endowment versus the structural effect depends in large part on whether gender is defined in terms of heads, holders or managers, and in the case of the last two, whether female plots are compared to only male plots, or plots with joint male-female decision-making. A greater share of the gap is attributable to the endowment effect when drawing comparisons across holders, as opposed to heads or managers. This finding could be related to the fact that gender is defined in terms of a physical asset - land possession - rather than a more abstract criterion such as household head, which has a degree of disconnect from plot operations.

[Table 8 here]

\section{Discussion and Conclusion}

Does the choice of the gender variable matter in the analysis of agricultural productivity? Our results suggest that it does, for two main reasons in particular. The first is that precision in the choice of gender variable helps to identify a role in decision-making (at the household or plot level) that potentially influences agricultural productivity. Identifying this role is important for targeting interventions that reach those who influence agricultural productivity. In this respect, the analysis shows that the gender variables at our disposition do not tell us with precision who in the household makes decisions on what aspects of agriculture (the gender of the plot manager may be the best approximation), such that we are constrained when it comes to identifying which individual's decisions need to be enhanced to increase productivity. In order to address this problem, surveys targeted at measuring the gender differentials in agricultural productivity should include questions that identify with more precision which members of a household make decisions across several aspects of crop production (e.g. crop or seed selection, input selection, planting, and harvesting). 
Second, in several contexts, the roles of men and women also overlap, tasks being shared in the same plot. We observed that all three male, joint and female plots show differences in agricultural productivity. Therefore, in the analysis of gender differences, it is important to consider the full range of categories, which is only made possible by surveys that allow multiple household members to be recorded in a particular role. The gender variable determines how plot samples are analyzed and compared to each other. We have observed differences in the factors that contribute to productivity, namely the percentage that explains gender differences in endowments and the percentage that explains gender differences in the returns to endowments. The Oaxaca decomposition allows us to understand the differences when running these comparisons. In addition to demonstrating that the endowment effects are of greater magnitude than the structural effects, the decomposition results suggest that both the endowment effect and the return to endowments are greater when comparing male and female plots, than between joint and female plots.

Beyond the gender variable of choice, our study emphasizes the importance of accounting for both observable and unobservable factors in studies that aim to explain how gender relations influence a determined outcome, in our case, agricultural productivity. Intra-household dynamics and discrimination are complex and difficult to measure by one gender variable. Our use of district and year fixed effects, as well as the use of longitudinal data, allowed us to control for a broad range of plot, parcel, household and spatial characteristics. The use of these methods is instructive as an attempt to shed light on agricultural decision-making processes related to gender by helping reduce the error term of the equation that potentially captures these gender relations.

Finally, the study reveals that beyond the influence of gender and gender dynamics, a number of additional factors are associated with lower agricultural productivity, and which can be more easily addressed by agricultural and social policies. For female plots in Uganda, an important factor is child dependency ratio since household care responsibilities tend to be undertaken by women, placing constraints on labor allocation to their plots. Female heads and plot holders/managers in Uganda are also significantly older than their male counterparts, which add to female labor constraints a potentially lower physical capacity to work. Access to labor - particularly male family labor - is associated with increased 
productivity in female plots; therefore, facilitating access to labor markets could address these constraints. The study also shows that overall, for all female and male plots in Uganda, the low access to agricultural inputs and extension is constraining agricultural productivity. These findings highlight concrete areas for policy action to increase productivity, particularly under Uganda's DSIP, which will seek to increase rural household incomes. Attention to gender-related issues, such as aging, access to labor, and childcare solutions, as well as adequate extension, rural advisory services, and access to agricultural inputs for all farmers could increase productivity, particularly in women's plots.

\section{References}

Agarwal, B., 2003. Gender and Land Rights Revisited: Exploring New Prospects via the State, Family and Market. Journal of Agrarian Change 3, 184-224.

Aguilar, A., Goldstein, M.P., Kilic, T., Oseni, G., 2014. Decomposition of Gender Differentials in Agricultural Productivity in Ethiopia. World Bank Policy Research Working Paper No. 6764.

Akresh, R., 2005. Understanding Pareto inefficient intrahousehold allocations. Institute for the Study of Labor (IZA) Discussion Paper No. 1858.

Alene, A.D., Manyong, V.M., Omanya, G.O., Mignouna, H.D., Bokanga, M., Odhiambo, G.D., 2008. Economic efficiency and supply response of women as farm managers: Comparative evidence from Western Kenya. World Development 36, 1247,„1a71260.

Blinder, A., 1973. Wage discrimination: reduced form and structural estimates. Journal of Human Resources 8, 436,1 1a7455.

Boserup, E., 1970. Woman's role in economic development. St Martin's Press, New York, NY.

Chavas, J.P., Petrie, R., Roth., M., 2005. Farm household production efficiency: evidence from the Gambia. American Journal of Agricultural Economics 87, 160-179.

Croppenstedt, A., Goldstein, M., Rosas, N., 2013. Gender and agriculture: Inefficiencies, segregation, and low productivity traps. The World Bank Research Observer 28, 79-109.

Dolan, C., 2002. Gender and diverse livelihoods in Uganda. LADDER Working Paper No.10.

Doss, C.R., 2001. Designing agricultural technology for African women farmers: Lessons from 25 years of experience. World Development 29, 2075-2092.

Doss, C.R., Kovarik, C., Peterman, A., Quisuming, A.R., Bold, M.V. den, 2013. Gender inequalities in ownership and control of land in Africa: Myth and Reality. IFPRI Discussion Paper 01308.

FAO, 2011. The State of Food and Agriculture 2010-11: Women in Agriculture. FAO, Rome, Italy.

FAO, 2015. Gender and Land Rights Database.

Fortin, T. N., Lemieux, Firpo, S., 2011. Decomposition methods in economics. Handbook of Labor Economics A4, 1-102.

Gilbert, R.A., Sakala, W.D., Benson, T.D., 2002. Gender analysis of a nationwide cropping system trial survey in Malawi. African Studies Quarterly 6.

Goldstein, M., Udry, C., 2008. The profits of power: Land rights and agricultural investment in Ghana. Journal of Political Economy 116, 981,1a71022.

Horrell, S., Krishnan, P., 2007. Poverty and productivity in female-headed households in Zimbabwe. Journal of Development Studies 43, 1351,1a780.

Howard, P.L., Nabanoga, G., 2007. Are there customary rights to plants? An inquiry among the Baganda (Uganda), with special attention to gender. World Development 35, 1542,,1a71563. 
Kasente, D., Lockwood, M., J. Vivian, Whitehead, A., 2002. Gender and the expansion of non-traditional agricultural exports in Uganda.

Kilic, T., Palacios-Lopez, A., Goldstein, M., 2013. Caught in a productivity trap: A distributional perspective on gender differences in Malawian agriculture. Policy Research Working Paper 6381, The World Bank.

Kleinjans, K., 2013. The man of the house „1 1 7 How the use of household head characteristics may lead to omitted variable bias. Economic Letters 119, 113-135.

McDonagh, J., Bahiigwa, G., 2002. Crop-Based Farming Systems and Diverse Livelihoods in Uganda. LADDER Working Paper 7, Overseas Development Institute (ODI). London: ODI.

Mukwaya, P., Bamutaze, Y., Mugarura, S., Benson., T., 2011. Rural-Urban Transformation in Uganda, in: Report conference "Understanding Economic TransformationSubSaharanAfrica. IFPRI, Accra, Ghana.

Oakley, A., 1972. Sex, gender, and society. Temple Smith, London, UK.

Oaxaca, R., 1973. Male-female wage differentials in urban labor markets. International Economic Review 14, 693,1a7709.

Oladeebo, J.O., Fajuyigbe, A.A., 2007. Technical efficiency of men and women upland rice farmers in Osun State, Nigeria. Journal of Human Ecology 22, 93,1,197100.

Oseni, G., Corral, P., Goldstein, M., Winters, P., 2014. Explaining Gender Differentials in Agricultural Production in Nigeria. Policy Research Working Paper 6809, The World Bank.

Peterman, A., Quisumbing, A., Behrman, J., Nkonya, E., 2010. Understanding gender differences in agricultural productivity in Uganda and Nigeria. IFPRI Discussion Paper 01003.

Quisumbing, A., Payongayong, E., Aidoo, J.B., Otsuka, K., 2001. Women's land rights in the transition to individualized ownership: Implications for the management of tree resources in western Ghana. Economic Development and Cultural Change 50,157,1,7182.

Quisumbing, A.R., 1996. Male-female differences in agricultural productivity: Methodological issues and empirical evidence. World Development 24, 1579,,1a71595.

Quisumbing, A.R., Maluccio., J.A., 2003. Intrahousehold allocation and gender relations: New empirical evidence from four developing countries. International Food Policy Research Institute (IFPRI), Washington DC.

Tiruneh, A., Testfaye, T., Mwangi, W., Verkuijl, H., 2001. Gender differentials in agricultural production and decision-making among smallholders in Ada, Lume, and Gimbichu woredas of the central highlands of Ethiopia. International Maize and Wheat Improvement Center and Ethiopian Agricultural Research Organization.

UBOS, 2002. Uganda Population and Housing Census: Main Report. http://www.ubos.org/onlinefiles/uploads/ubos/pdf\%20documents/2002\%20Census\%20Final\%20R eportdoc.pdf.

UBS, 2011. The Uganda National Panel Survey (UNPS) 2010/11. Basic Information Document.

Udry, C., 1996. Gender, agricultural production, and the theory of the household. Journal of Political Economy 104, 1010,1a71046.

Udry, C., Hoddinott, J., Alderman, H., Haddad, L., 1995. Gender differentials in farm productivity: Implications for household efficiency and agricultural policy. Food Policy 20, 407,1107423.

Vargas Hill, R., Vigneri, M., 2011. Mainstreaming gender sensitivity in cash crop markets supply chains. Working Paper No. 11-08, ESA, FAO.

WDI, 2015. World development indicators on-line database. 
Tables \& Figures

Table 1: Descriptive Statistics of different gender-based plot samples - Uganda (2010-11)

Plots by head of household

Production and Productivity

Household head is female First reported holder is female

Individual characteristics of the first reported person

$$
\begin{array}{rr}
\text { Age } & 45.1 \\
\text { Years of schooling } & 5.68 \\
\text { Monogamously married } & 0.74 \\
\text { Polygamously married } & 0.20 \\
\text { Divorced } & 0.031 \\
\text { Widowed } & 0.017 \\
\text { Single } & 0.0073
\end{array}
$$

Individual characteristics of the second reported person

$$
\text { Second Female }
$$$$
\text { Second Age }
$$

Second Years of schooling

Second monogamously married

Second polygamously married

Second Divorced

Second Widowed

Second Single

Household characteristics

Number of individuals age 15 and older
Plots by holder

Only Female

F

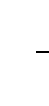

3838

Only Male

1629

1475

318330.2

1081293.2

129929.5

175765.3

111725.1

181466.5

87193.2

77217.1

$\begin{array}{rr}0 & 1 \\ 0.049 & 0.95^{\star \star \star}\end{array}$

0.10
0.12

45.2
5.55
0.72
0.21
0.018
0.038
0.0057

314698.4

1098630.1

204888. $9^{\star * \star *}$

98450.8*

145392.9

84336.4

262871.1*

49921.4*

1017277.8

97332.0*

142955.2

91463.7

183968.5

90562.8

$0.025^{\star \star \star}$

0

$0.92^{\star \star \star}$

$50.9^{\star \star *}$

$2.54^{\star \star *}$

\begin{tabular}{|c|c|}
\hline 44.3 & $51.1^{\star \star \star \star}$ \\
\hline $5.18^{* *}$ & $2.64^{\star \star \star}$ \\
\hline $0.66^{\star \star \star}$ & $0.12^{\star \star \star}$ \\
\hline $0.18^{\star}$ & $0.18^{*}$ \\
\hline $0.089^{\star \star \star}$ & $0.22^{\star \star \star}$ \\
\hline 0.046 & $0.46^{\star \star * *}$ \\
\hline $0.021^{\star \star}$ & $0.021^{\star \star}$ \\
\hline
\end{tabular}

$0.11^{\star \star \star}$

0.21

$$
0.21^{\star \star *}
$$

$0.46^{\star \star \star}$

$0.015^{\star}$

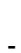

-
-
-
-
-
-
-
-

$3.102 .57^{\star \star \star}$
0.88

37.4

3.80

0.74

0.20

0.0061

0.0036

0.058

3.21

$\begin{array}{rr}0 & 1 \\ 43.3^{\star \star \star} & 47.1^{\star \star \star}\end{array}$

$5.15^{\star \star \star} \quad 2.69^{\star \star \star}$

$0.65^{\star \star \star} \quad 0.12^{\star \star \star}$

$0.17^{\star} \quad 0.16^{*}$

$0.086^{\star \star *} \quad 0.23^{\star \star *}$

$0.047^{\star \star \star} \quad 0.38^{\star \star \star}$

$0.047 \quad 0.11^{\star \star \star}$

$2.79^{\star \star \star} \quad 2.50^{\star \star \star}$
Plots by manager of output

\begin{tabular}{rrr}
\multicolumn{1}{c}{ Joint } & \multicolumn{1}{c}{ Only Male } & Only Female \\
\hline \multicolumn{1}{l}{4320} & \multicolumn{1}{c}{798} & \multicolumn{1}{c}{1824} \\
& & \\
319982.9 & 311974.8 & $\mathbf{2 2 0 9 5 8 . 2}^{\star \star *}$ \\
1072104.6 & 1103813.9 & 1055515.4 \\
118304.2 & 130135.8 & 102863.0 \\
163478.3 & 179776.2 & 149312.3 \\
110576.1 & $\mathbf{7 2 5 1 7 . 8}$ & 91782.8 \\
185058.7 & 266703.9 & 207474.9 \\
83312.0 & $\mathbf{4 6 7 1 6 . 0 ^ { * }}$ & 85000.1
\end{tabular}

$\begin{array}{lll}0.085 & 0.029^{\star \star *} & 0.77^{\star \star *}\end{array}$

$0.10 \quad 0.028^{\star \star \star} \quad 0.83^{\star \star \star}$

$44.7 \quad 45.0$

$5.33 \quad 5.17$

$0.034 \quad 0.029$

$0.20 \quad 0.16^{\star}$

0.019

$0.16^{\star \star *}$

$0.077^{\star *}$

$0.045^{\star \star \star}$

$48.0^{\star \star \star}$

$2.98^{\star \star \star}$

$0.056^{\star \star *}$

0.22

$0.18^{\star \star \star}$

$0.36^{\star \star \star}$

$0.026^{\star * *}$

$$
0.86
$$

37.1

3.75

0.023

0.18

0.0060

0.0043

0.056

42. . $^{\text {*** }}$

$5.13^{\star \star \star}$

0.026

$0.14^{*}$

$0.14^{\star \star \star}$

$0.081^{\text {** }}$

$0.11^{\star \star \star}$

3.18

$2.49^{\star \star *}$ 
Child dependency ratio, 10yrs cut off

$$
\text { Labor income }
$$

Household Wealth Index

Plot characteristics

Share of plots owned (not use rights) Share of plots with titles

Land area (acres)

Intercropping system

Good quality of soil and flat

Irrigation is the main source of water

Plot is at +30 min walking distance

Labor and Inputs

$$
\begin{array}{r}
\text { Days worked per acre/ } 100 \\
\text { Use of hired labor } \\
\text { Female adult family labour used on plot } \\
\text { Male adult family labour used on plot } \\
\text { Child family labour used on plot } \\
\text { Use of organic or inorganic fertilizer } \\
\text { Use of pesticides } \\
\text { Household received technical assistance }
\end{array}
$$

\section{Market orientation and crop choice}

Production is sold in the marke

$$
\begin{array}{r}
\text { Maize } \\
\text { Beans } \\
\text { Cassava } \\
\text { Banana Food } \\
\text { Sweet Potato }
\end{array}
$$

Share of plot cultivating staple crops

\begin{abstract}
0.33
\end{abstract}$$
0.32
$$

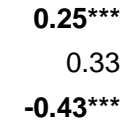

0.34

0.33

0.13

$0.30^{* \star *}$

0.31

0.091

$0.26^{\star \star \star}$

0.31

$\begin{array}{ll}0.81 & 0.80\end{array}$

$$
0.13
$$$$
0.85
$$$$
0.43
$$$$
0.064
$$

0.022

0.19

0.11

$0.68^{*}$

0.44

0.065

$0.045^{\star \star \star}$

0.18

0.81

0.13

0.85

0.43

0.066

0.026

0.18

$0.86^{\star \star *}$

0.14

0.83

0.44

$0.047^{\star}$

$0.014^{\star \star}$

0.18

2.56

$2.89^{\text {** }}$

$0.30^{\star *}$

$0.96^{\star \star *}$

$0.41^{\star \star *}$

$0.44^{\star \star \star}$

$0.060^{\text {** }}$

$0.031^{\star \star \star}$

$0.19^{\star \star *}$

0.34

0.95

0.86

0.29

0.075

0.055

0.26

0.70

0.27

0.32

0.29

0.16

$\mathbf{0 . 2 2}$ *

0.64

0.71

0.29

0.30

0.28

0.17

0.18

0.62

2.58

0.34

$0.81^{\star \star \star}$

$0.90^{\star \star \star}$

0.28

0.095

0.078 **

0.24

0.73

0.28

0.29

0.30

0.19

0.19

0.61

$0.75^{\star \star}$

$0.091^{\star \star \star}$

$0.64^{\star}$

0.43

0.080

$0.048^{\star *}$

$0.21^{*}$

2.95*

0.31

$0.97^{*}$

$0.34^{\star \star \star}$

$0.44^{\star \star \star}$

0.062

$0.032^{\star \star \star}$

$0.19^{\star \star \star}$

0.71

0.28

0.32

0.29

0.16

$0.22^{*}$

0.64

$0.19^{\star \star \star} \quad 0.098$

$0.24^{\star \star \star}$

0.28

0.29

$0.20^{\star \star \star}$

$0.22^{\star \star \star}$

$0.30 \quad \mathbf{0 . 2 3}^{\text {***}}$

0.28

$0.22^{\star \star \star}$

0.25

0.31

0.34

$0.30^{*}$

Western region

Note: UNPS 2010-11; The estimates are weighted in accordance with the complex survey design;

statistical significance is indicated as follows ${ }^{* * *} p<0.01,{ }^{* *} p<0.05,{ }^{*} p<0.1$ 
Figure 1: Agricultural Productivity Distribution - Kernel Density Estimations - Uganda (UNPS 2010-11)

Different gender variables of choice, according to household headship, plot holding and plot management: Joint, Male and Female
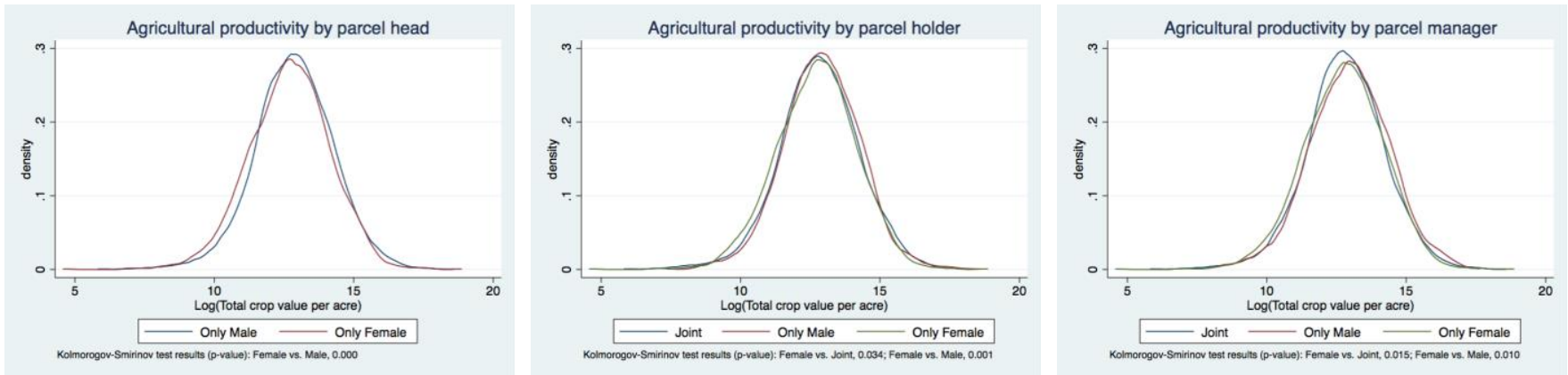
Table 2: Base OLS Regression Results on Gender Differences in Agricultural Productivity in Uganda (2010-11)

Dependent Variable: Log[Plot Gross Annual Value of Output per Acre]

\begin{tabular}{|c|c|c|c|c|c|c|c|c|c|c|c|c|c|c|}
\hline & \multicolumn{4}{|c|}{ Household Head } & \multicolumn{5}{|c|}{ Plot Holder } & \multicolumn{5}{|c|}{ Manager of Plot Output } \\
\hline & Naïve & $\begin{array}{l}\text { Pooled } \\
\text { Sample }\end{array}$ & $\begin{array}{l}\text { MHH } \\
\text { Plots }\end{array}$ & $\begin{array}{l}\text { FHH } \\
\text { Plots }\end{array}$ & Naïve & $\begin{array}{l}\text { Pooled } \\
\text { Sample }\end{array}$ & $\begin{array}{l}\text { Only } \\
\text { male }\end{array}$ & Joint & $\begin{array}{l}\text { Only } \\
\text { female }\end{array}$ & Naïve & $\begin{array}{l}\text { Pooled } \\
\text { Sample }\end{array}$ & $\begin{array}{l}\text { Only } \\
\text { male }\end{array}$ & Joint & $\begin{array}{l}\text { Only } \\
\text { female }\end{array}$ \\
\hline & (1) & (2) & (3) & (4) & (5) & (6) & (7) & (8) & (9) & (10) & (11) & (12) & (13) & (14) \\
\hline \multirow[t]{2}{*}{ Only Female § } & $-0.152^{\star \star \star}$ & -0.025 & & & $-0.193^{\star \star \star}$ & -0.004 & & & & $-0.153^{\star \star \star}$ & $-0.096^{\star \star}$ & & & \\
\hline & $(0.046)$ & $(0.064)$ & & & $(-0.048)$ & $(0.062)$ & & & & $(0.046)$ & $(0.043)$ & & & \\
\hline \multicolumn{15}{|c|}{ Individual and Household Characteristics } \\
\hline \multirow[t]{2}{*}{ Age (Years) } & & $0.016^{\star \star}$ & $0.024^{\star \star \star}$ & $-0.023^{\star}$ & & $0.015^{\star \star}$ & 0.008 & $0.032^{\star \star \star}$ & $-0.033^{\star \star}$ & & $0.023^{\star \star \star}$ & 0.000 & $0.030^{\star \star \star}$ & 0.005 \\
\hline & & $(0.007)$ & $(0.008)$ & $(0.014)$ & & $(0.007)$ & $(0.012)$ & $(0.011)$ & $(0.015)$ & & $(0.007)$ & $(0.024)$ & $(0.010)$ & $(0.013)$ \\
\hline \multirow[t]{2}{*}{ Age squared/100 } & & $-0.017^{\star \star \star}$ & $-0.023^{\star \star \star}$ & 0.012 & & $-0.016^{\star *}$ & -0.009 & $-0.028^{\star \star \star}$ & 0.018 & & $-0.025^{\star \star \star}$ & -0.003 & $-0.030^{\star \star *}$ & -0.009 \\
\hline & & $(0.006)$ & $(0.008)$ & $(0.012)$ & & $(0.006)$ & $(0.012)$ & $(0.010)$ & $(0.013)$ & & $(0.007)$ & $(0.024)$ & $(0.010)$ & $(0.012)$ \\
\hline \multirow[t]{2}{*}{ Years of schooling } & & 0.006 & -0.006 & 0.001 & & 0.007 & -0.036 & 0.017 & -0.020 & & 0.004 & $-0.126^{\star \star \star}$ & 0.009 & 0.042 \\
\hline & & $(0.013)$ & $(0.015)$ & $(0.027)$ & & $(0.013)$ & $(0.029)$ & $(0.017)$ & $(0.031)$ & & $(0.013)$ & $(0.047)$ & $(0.016)$ & (0.032) \\
\hline \multirow[t]{2}{*}{$\begin{array}{r}\text { Years of schooling } \\
\text { squared } / 100\end{array}$} & & -0.100 & -0.050 & 0.095 & & -0.091 & 0.319 & -0.215 & 0.310 & & -0.071 & $1.138^{\star \star \star}$ & -0.163 & -0.341 \\
\hline & & $(0.111)$ & $(0.126)$ & $(0.241)$ & & $(0.110)$ & $(0.273)$ & $(0.141)$ & $(0.326)$ & & $(0.116)$ & $(0.413)$ & $(0.146)$ & (0.357) \\
\hline \multirow[t]{2}{*}{$\begin{array}{l}\text { Polygamous } \\
\text { married } \S\end{array}$} & & 0.075 & $0.087^{\star}$ & 0.136 & & $0.081^{*}$ & 0.064 & 0.092 & 0.171 & & -0.021 & -0.694 & 0.060 & 0.032 \\
\hline & & $(0.047)$ & $(0.051)$ & $(0.130)$ & & $(0.045)$ & $(0.088)$ & $(0.061)$ & $(0.136)$ & & $(0.087)$ & $(0.491)$ & $(0.112)$ & (0.119) \\
\hline \multirow[t]{2}{*}{$\begin{array}{r}\text { Unmarried } \\
\text { (Divorced; } \\
\text { Widowed; Single) § }\end{array}$} & & -0.065 & -0.188 & 0.067 & & -0.076 & $-0.319^{\star \star}$ & 0.003 & 0.080 & & $0.105^{\star \star}$ & $0.553^{\star \star \star}$ & 0.013 & $0.179^{\star \star}$ \\
\hline & & $(0.069)$ & $(0.131)$ & $(0.116)$ & & $(0.063)$ & $(0.159)$ & $(0.108)$ & $(0.111)$ & & $(0.043)$ & $(0.190)$ & $(0.052)$ & $(0.090)$ \\
\hline \multirow[t]{2}{*}{$\begin{array}{r}\text { Household } \\
\text { members age 15+ }\end{array}$} & & $0.024^{\star}$ & 0.009 & $0.072^{\star \star \star}$ & & $0.025^{\star}$ & 0.032 & 0.002 & $0.052^{\star}$ & & 0.023 & $0.097^{\star}$ & 0.011 & $0.043^{\star}$ \\
\hline & & $(0.014)$ & $(0.018)$ & $(0.027)$ & & $(0.015)$ & $(0.031)$ & $(0.020)$ & (0.029) & & $(0.014)$ & $(0.057)$ & (0.019) & $(0.024)$ \\
\hline
\end{tabular}




\begin{tabular}{|c|c|c|c|c|c|c|c|c|c|c|c|}
\hline \multirow[t]{2}{*}{$\begin{array}{l}\text { Child dependency } \\
\text { ratio (10yrs cut-off) }\end{array}$} & -0.046 & 0.022 & $-0.291^{*}$ & -0.044 & -0.039 & -0.004 & -0.180 & 0.001 & -0.407 & 0.066 & -0.212 \\
\hline & $(0.099)$ & $(0.121)$ & $(0.164)$ & $(0.099)$ & $(0.196)$ & $(0.159)$ & $(0.167)$ & $(0.101)$ & $(0.336)$ & $(0.142)$ & $(0.167)$ \\
\hline \multirow[t]{2}{*}{$\begin{array}{l}\text { Participation non- } \\
\text { agr wage labor } \S\end{array}$} & -0.017 & 0.015 & -0.094 & -0.021 & $-0.160^{\star *}$ & $0.107^{\star}$ & $-0.204^{\star \star}$ & -0.014 & -0.132 & 0.051 & -0.095 \\
\hline & $(0.043)$ & $(0.050)$ & $(0.077)$ & $(0.042)$ & $(0.082)$ & $(0.058)$ & $(0.081)$ & $(0.042)$ & $(0.172)$ & $(0.050)$ & $(0.079)$ \\
\hline $\begin{array}{r}\text { PCA Wealth Asset } \\
\text { Index }\end{array}$ & $\begin{array}{r}0.022 \\
(0.016)\end{array}$ & $\begin{array}{r}0.028 \\
(0.019)\end{array}$ & $\begin{array}{l}-0.002 \\
(0.026)\end{array}$ & $\begin{array}{r}0.020 \\
(0.016)\end{array}$ & $\begin{array}{r}0.038 \\
(0.024)\end{array}$ & $\begin{array}{r}0.010 \\
(0.021)\end{array}$ & $\begin{array}{l}-0.037 \\
(0.030)\end{array}$ & $\begin{array}{r}0.023 \\
(0.016)\end{array}$ & $\begin{array}{r}0.008 \\
(0.037)\end{array}$ & $\begin{array}{r}0.026 \\
(0.020)\end{array}$ & $\begin{array}{l}-0.019 \\
(0.026)\end{array}$ \\
\hline \multicolumn{12}{|l|}{$\begin{array}{l}\text { Plot } \\
\text { Characteristics }\end{array}$} \\
\hline \multirow[t]{2}{*}{ Plot owned § } & 0.075 & 0.067 & 0.121 & 0.076 & 0.099 & 0.054 & 0.137 & 0.072 & 0.295 & 0.035 & 0.058 \\
\hline & $(0.055)$ & $(0.066)$ & $(0.104)$ & $(0.055)$ & $(0.135)$ & $(0.076)$ & $(0.100)$ & $(0.055)$ & $(0.182)$ & $(0.071)$ & $(0.098)$ \\
\hline Log Plot Size & $\begin{array}{r}-0.360^{\star \star \star} \\
(0.021)\end{array}$ & $\begin{array}{r}-0.355^{\star \star *} \\
(0.025)\end{array}$ & $\begin{array}{r}-0.377^{\star \star \star} \\
(0.037)\end{array}$ & $\begin{array}{r}-0.360^{\star \star \star} \\
(0.021)\end{array}$ & $\begin{array}{r}-0.400^{\star \star *} \\
(0.041)\end{array}$ & $\begin{array}{r}-0.314^{\star \star \star} \\
(0.028)\end{array}$ & $\begin{array}{r}-0.383^{\star \star \star} \\
(0.043)\end{array}$ & $\begin{array}{r}-0.358^{\star \star \star} \\
(0.021)\end{array}$ & $\begin{array}{r}-0.417^{\star \star \star} \\
(0.063)\end{array}$ & $\begin{array}{r}-0.321^{\star \star *} \\
(0.027)\end{array}$ & $\begin{array}{r}-0.383^{\star \star \star} \\
(0.042)\end{array}$ \\
\hline $\begin{array}{r}\text { Good quality of soil } \\
\text { and flat } \S\end{array}$ & $\begin{array}{r}0.275^{\star \star \star} \\
(0.093)\end{array}$ & $\begin{array}{l}0.277^{\star \star} \\
(0.112)\end{array}$ & $\begin{array}{r}0.236 \\
(0.160)\end{array}$ & $\begin{array}{r}0.279^{\star \star \star} \\
(0.093)\end{array}$ & $\begin{array}{r}0.185 \\
(0.238)\end{array}$ & $\begin{array}{l}0.296^{\star \star} \\
(0.130)\end{array}$ & $\begin{array}{r}0.221 \\
(0.152)\end{array}$ & $\begin{array}{r}0.281^{\star \star \star} \\
(0.094)\end{array}$ & $\begin{array}{r}0.594 \\
(0.365)\end{array}$ & $\begin{array}{l}0.240^{\star \star} \\
(0.122)\end{array}$ & $\begin{array}{r}0.237 \\
(0.157)\end{array}$ \\
\hline \multirow[t]{2}{*}{$\begin{array}{l}\text { Main water source } \\
\text { is irrigation } \S\end{array}$} & -0.086 & -0.166 & 0.027 & -0.088 & $-0.586^{\star \star *}$ & -0.049 & 0.186 & -0.089 & -0.068 & -0.053 & -0.125 \\
\hline & $(0.106)$ & $(0.131)$ & $(0.185)$ & $(0.105)$ & $(0.208)$ & $(0.151)$ & $(0.225)$ & $(0.103)$ & $(0.271)$ & $(0.142)$ & $(0.190)$ \\
\hline \multirow[t]{2}{*}{$\begin{array}{r}\text { Distance from } \\
\text { holding }>30 \text { min } \S\end{array}$} & -0.006 & -0.053 & 0.047 & -0.007 & -0.116 & -0.017 & 0.096 & -0.008 & 0.061 & -0.016 & -0.005 \\
\hline & $(0.047)$ & $(0.055)$ & $(0.082)$ & $(0.047)$ & $(0.091)$ & $(0.061)$ & $(0.084)$ & $(0.047)$ & $(0.163)$ & $(0.057)$ & $(0.086)$ \\
\hline \multicolumn{12}{|l|}{ Labor and Inputs } \\
\hline Hired labor $\S$ & $\begin{array}{r}0.301^{\star \star \star} \\
(0.040)\end{array}$ & $\begin{array}{r}0.339^{\star \star \star} \\
(0.048)\end{array}$ & $\begin{array}{r}0.208^{\star \star \star} \\
(0.068)\end{array}$ & $\begin{array}{r}0.299^{\star \star \star} \\
(0.040)\end{array}$ & $\begin{array}{r}0.377^{\star \star \star} \\
(0.093)\end{array}$ & $\begin{array}{r}0.309^{\star \star \star} \\
(0.053)\end{array}$ & $\begin{array}{r}0.276^{\star \star \star} \\
(0.080)\end{array}$ & $\begin{array}{r}0.295^{\star \star \star} \\
(0.039)\end{array}$ & $\begin{array}{r}0.461^{\star * \star} \\
(0.164)\end{array}$ & $\begin{array}{r}0.317^{\star \star \star} \\
(0.049)\end{array}$ & $\begin{array}{r}0.235^{\star \star \star} \\
(0.074)\end{array}$ \\
\hline \multirow[t]{2}{*}{$\begin{array}{r}\text { Male adult family } \\
\text { labour used on plot } \\
\S\end{array}$} & $0.205^{\star \star \star}$ & $0.351^{\star \star \star}$ & 0.012 & $0.212^{\star \star \star}$ & $0.299^{\star \star \star}$ & $0.310^{\star \star \star}$ & 0.041 & $0.229^{\star \star \star}$ & $0.537^{\star \star \star}$ & $0.303^{\star \star \star}$ & $0.143^{\star \star}$ \\
\hline & $(0.047)$ & $(0.069)$ & $(0.068)$ & $(0.050)$ & $(0.129)$ & $(0.073)$ & $(0.077)$ & $(0.050)$ & $(0.203)$ & $(0.079)$ & $(0.071)$ \\
\hline $\begin{array}{r}\text { Female adult family } \\
\text { labour used on plot } \\
\S\end{array}$ & 0.036 & -0.007 & 0.206 & 0.029 & 0.030 & -0.056 & -0.121 & 0.042 & 0.176 & -0.108 & 0.088 \\
\hline
\end{tabular}




\begin{tabular}{|c|c|c|c|c|c|c|c|c|c|c|c|}
\hline & $(0.086)$ & $(0.103)$ & $(0.131)$ & $(0.087)$ & $(0.142)$ & $(0.144)$ & $(0.170)$ & $(0.088)$ & $(0.177)$ & $(0.138)$ & $(0.153)$ \\
\hline \multirow[t]{2}{*}{$\begin{array}{l}\text { Child family labour } \\
\text { used on plot } \S\end{array}$} & 0.019 & -0.015 & 0.091 & 0.019 & -0.036 & 0.011 & 0.096 & 0.011 & -0.081 & -0.006 & 0.080 \\
\hline & $(0.037)$ & $(0.047)$ & $(0.068)$ & $(0.037)$ & $(0.080)$ & $(0.054)$ & $(0.072)$ & $(0.037)$ & $(0.153)$ & $(0.048)$ & $(0.068)$ \\
\hline Use of fertilizer $\S$ & $\begin{array}{l}0.298^{\star * *} \\
(0.068)\end{array}$ & $\begin{array}{l}0.245^{\star * *} \\
(0.076)\end{array}$ & $\begin{array}{l}0.355^{\star \star \star} \\
(0.126)\end{array}$ & $\begin{array}{l}0.298^{\star * \star} \\
(0.068)\end{array}$ & $\begin{array}{l}0.201^{\star * *} \\
(0.123)\end{array}$ & $\begin{array}{l}0.332^{\star \star \star} \\
(0.085)\end{array}$ & $\begin{array}{l}0.342^{\star \star} \\
(0.140)\end{array}$ & $\begin{array}{l}0.301^{\star \star *} \\
(0.067)\end{array}$ & $\begin{array}{l}-0.030 \\
(0.242)\end{array}$ & $\begin{array}{l}0.335^{\star \star \star} \\
(0.079)\end{array}$ & $\begin{array}{l}0.240^{\star} \\
(0.137)\end{array}$ \\
\hline Use of pesticides $\S$ & $\begin{array}{l}0.298^{\star \star \star} \\
(0.070)\end{array}$ & $\begin{array}{r}0.320^{\star \star \star} \\
(0.079)\end{array}$ & $\begin{array}{r}0.022 \\
(0.162)\end{array}$ & $\begin{array}{l}0.297^{\star \star \star} \\
(0.070)\end{array}$ & $\begin{array}{r}0.087^{\star \star \star} \\
(0.135)\end{array}$ & $\begin{array}{l}0.360^{\star \star \star} \\
(0.088)\end{array}$ & $\begin{array}{r}0.214 \\
(0.198)\end{array}$ & $\begin{array}{r}0.296^{\star \star \star} \\
(0.070)\end{array}$ & $\begin{array}{r}0.110 \\
(0.186)\end{array}$ & $\begin{array}{r}0.323^{\star \star \star} \\
(0.083)\end{array}$ & $\begin{array}{l}0.287^{*} \\
(0.165)\end{array}$ \\
\hline $\begin{array}{r}\mathrm{HH} \text { member } \\
\text { received technical } \\
\text { assistance } \S\end{array}$ & $\begin{array}{l}0.075^{\star} \\
(0.041)\end{array}$ & $\begin{array}{l}0.089^{\star} \\
(0.047)\end{array}$ & $\begin{array}{r}0.067 \\
(0.084)\end{array}$ & $\begin{array}{l}0.074^{\star} \\
(0.041)\end{array}$ & $\begin{array}{r}0.036 \\
(0.094)\end{array}$ & $\begin{array}{r}0.073 \\
(0.055)\end{array}$ & $\begin{array}{r}0.149 \\
(0.106)\end{array}$ & $\begin{array}{l}0.072^{\star} \\
(0.041)\end{array}$ & $\begin{array}{l}-0.213 \\
(0.215)\end{array}$ & $\begin{array}{r}0.078 \\
(0.051)\end{array}$ & $\begin{array}{r}0.086 \\
(0.087)\end{array}$ \\
\hline \multicolumn{12}{|l|}{ Crop Choice } \\
\hline Maize $\S$ & $\begin{array}{r}0.409^{\star * *} \\
(0.041)\end{array}$ & $\begin{array}{r}0.425^{\star * *} \\
(0.049)\end{array}$ & $\begin{array}{r}0.363^{\star \star \star} \\
(0.068)\end{array}$ & $\begin{array}{r}0.410^{\star \star \star} \\
(0.041)\end{array}$ & $\begin{array}{r}0.379^{\star * *} \\
(0.078)\end{array}$ & $\begin{array}{r}0.472^{\star \star \star} \\
(0.058)\end{array}$ & $\begin{array}{r}0.322^{\star * *} \\
(0.082)\end{array}$ & $\begin{array}{r}0.408^{\star \star *} \\
(0.041)\end{array}$ & $\begin{array}{r}0.478^{\star \star \star} \\
(0.111)\end{array}$ & $\begin{array}{r}0.420^{\star * *} \\
(0.055)\end{array}$ & $\begin{array}{r}0.354^{\star \star \star} \\
(0.075)\end{array}$ \\
\hline Beans $\S$ & $\begin{array}{r}0.495^{\star \star \star} \\
(0.041)\end{array}$ & $\begin{array}{r}0.480^{\star \star \star} \\
(0.050)\end{array}$ & $\begin{array}{r}0.550^{\star \star \star} \\
(0.066)\end{array}$ & $\begin{array}{r}0.495^{\star \star \star} \\
(0.041)\end{array}$ & $\begin{array}{r}0.492^{\star \star \star} \\
(0.079)\end{array}$ & $\begin{array}{l}0.460^{\star \star \star} \\
(0.059)\end{array}$ & $\begin{array}{r}0.625^{\star \star \star} \\
(0.075)\end{array}$ & $\begin{array}{c}0.497^{\star \star \star} \\
(0.041)\end{array}$ & $\begin{array}{l}0.554^{\star \star \star} \\
(0.103)\end{array}$ & $\begin{array}{r}0.481^{\star \star \star} \\
(0.055)\end{array}$ & $\begin{array}{r}0.550^{\star \star \star} \\
(0.072)\end{array}$ \\
\hline Cassava $\S$ & $\begin{array}{r}0.342^{\star \star \star} \\
(0.037)\end{array}$ & $\begin{array}{r}0.315^{\star \star \star} \\
(0.047)\end{array}$ & $\begin{array}{r}0.428^{\star \star \star} \\
(0.059)\end{array}$ & $\begin{array}{r}0.343^{\star \star \star} \\
(0.037)\end{array}$ & $\begin{array}{r}0.223^{\star \star \star} \\
(0.076)\end{array}$ & $\begin{array}{r}0.386^{\star \star \star} \\
(0.052)\end{array}$ & $\begin{array}{r}0.423^{\star \star \star} \\
(0.070)\end{array}$ & $\begin{array}{r}0.343^{\star \star \star} \\
(0.037)\end{array}$ & $\begin{array}{r}0.175 \\
(0.125)\end{array}$ & $\begin{array}{c}0.367^{\star \star \star} \\
(0.049)\end{array}$ & $\begin{array}{r}0.392^{\star \star \star} \\
(0.064)\end{array}$ \\
\hline Banana Food § & $\begin{array}{c}1.021^{\star \star \star} \\
(0.053)\end{array}$ & $\begin{array}{c}0.997^{\star \star \star} \\
(0.063)\end{array}$ & $\begin{array}{c}1.116^{\star \star \star} \\
(0.084)\end{array}$ & $\begin{array}{c}1.021^{\star \star \star} \\
(0.053)\end{array}$ & $\begin{array}{c}1.156^{\star \star *} \\
(0.121)\end{array}$ & $\begin{array}{r}0.946^{\star \star \star} \\
(0.068)\end{array}$ & $\begin{array}{r}1.115^{\star \star \star} \\
(0.094)\end{array}$ & $\begin{array}{c}1.024^{\star \star \star} \\
(0.053)\end{array}$ & $\begin{array}{c}1.078^{\star \star \star} \\
(0.161)\end{array}$ & $\begin{array}{c}1.012^{\star \star \star} \\
(0.065)\end{array}$ & $\begin{array}{r}1.049^{\star \star \star} \\
(0.093)\end{array}$ \\
\hline Sweet Potato $\S$ & $\begin{array}{r}0.342^{\star \star \star} \\
(0.043)\end{array}$ & $\begin{array}{r}0.311^{\star \star \star} \\
(0.054)\end{array}$ & $\begin{array}{r}0.431^{\star \star \star} \\
(0.069)\end{array}$ & $\begin{array}{r}0.342^{\star \star \star} \\
(0.043)\end{array}$ & $\begin{array}{r}0.323^{\star \star \star} \\
(0.085)\end{array}$ & $\begin{array}{r}0.323^{\star \star \star} \\
(0.062)\end{array}$ & $\begin{array}{r}0.450^{\star \star \star} \\
(0.076)\end{array}$ & $\begin{array}{r}0.344^{\star \star \star} \\
(0.043)\end{array}$ & $\begin{array}{c}0.261^{*} \\
(0.141)\end{array}$ & $\begin{array}{c}0.393^{\star \star \star} \\
(0.056)\end{array}$ & $\begin{array}{r}0.353^{\star \star \star} \\
(0.079)\end{array}$ \\
\hline Coffee $\S$ & $\begin{array}{r}0.249^{\star \star \star} \\
(0.065)\end{array}$ & $\begin{array}{r}0.242^{\star \star \star} \\
(0.080)\end{array}$ & $\begin{array}{r}0.279^{\star \star \star} \\
(0.104)\end{array}$ & $\begin{array}{r}0.249^{\star \star \star} \\
(0.065)\end{array}$ & $\begin{array}{r}0.163 \\
(0.136)\end{array}$ & $\begin{array}{r}0.247^{\star \star \star} \\
(0.092)\end{array}$ & $\begin{array}{r}0.322^{\star \star \star} \\
(0.120)\end{array}$ & $\begin{array}{r}0.248^{\star \star \star} \\
(0.065)\end{array}$ & $\begin{array}{r}0.180 \\
(0.183)\end{array}$ & $\begin{array}{r}0.301^{\star \star \star} \\
(0.089)\end{array}$ & $\begin{array}{l}0.269^{\star \star} \\
(0.117)\end{array}$ \\
\hline $\begin{array}{r}\text { Proportion of plot } \\
\text { cultivating staple } \\
\text { crops }\end{array}$ & $\begin{array}{r}-0.854^{\star \star \star} \\
(0.057)\end{array}$ & $\begin{array}{r}-0.870^{\star \star \star} \\
(0.068)\end{array}$ & $\begin{array}{r}-0.785^{\star \star \star} \\
(0.104)\end{array}$ & $\begin{array}{r}-0.852^{\star * \star} \\
(0.057)\end{array}$ & $\begin{array}{r}-0.968^{\star \star \star} \\
(0.109)\end{array}$ & $\begin{array}{r}-0.829^{\star * \star} \\
(0.081)\end{array}$ & $\begin{array}{r}-0.755^{\star \star \star} \\
(0.118)\end{array}$ & $\begin{array}{r}-0.856^{\star \star \star} \\
(0.057)\end{array}$ & $\begin{array}{c}-0.871^{\star \star \star} \\
(0.164)\end{array}$ & $\begin{array}{r}-0.890^{\star \star *} \\
(0.074)\end{array}$ & $\begin{array}{r}-0.809^{\star \star \star} \\
(0.113)\end{array}$ \\
\hline $\begin{array}{l}\text { Production is } \\
\text { marketed } \S\end{array}$ & $\begin{array}{c}0.486^{\star * \star} \\
(0.040)\end{array}$ & $\begin{array}{c}0.455^{\star \star \star} \\
(0.048)\end{array}$ & $\begin{array}{c}0.563^{\star \star \star} \\
(0.070)\end{array}$ & $\begin{array}{l}0.485^{\star \star \star} \\
(0.040)\end{array}$ & $\begin{array}{c}0.462^{\star * \star} \\
(0.077)\end{array}$ & $\begin{array}{c}0.456^{\star \star \star} \\
(0.057)\end{array}$ & $\begin{array}{l}0.522^{\star \star \star} \\
(0.081)\end{array}$ & $\begin{array}{c}0.485^{\star \star \star} \\
(0.040)\end{array}$ & $\begin{array}{c}0.584^{\star \star \star} \\
(0.113)\end{array}$ & $\begin{array}{c}0.401^{\star * *} \\
(0.053)\end{array}$ & $\begin{array}{c}0.583^{\star \star \star} \\
(0.071)\end{array}$ \\
\hline
\end{tabular}




\begin{tabular}{|c|c|c|c|c|c|c|c|c|c|c|c|c|c|c|}
\hline _cons & $\begin{array}{r}12.873^{\star *} \\
\text { * } \\
(0.024)\end{array}$ & $\begin{array}{r}11.305^{\star \star} \\
\text { * } \\
(0.209)\end{array}$ & $\begin{array}{r}11.095^{\star *} \\
\text { * } \\
(0.256)\end{array}$ & $\begin{array}{r}11.978^{* \star} \\
\text { * } \\
(0.411)\end{array}$ & $\begin{array}{r}12.875^{\star *} \\
\text { * } \\
(0.023)\end{array}$ & $\begin{array}{r}11.306^{\star *} \\
\text { * } \\
(0.209)\end{array}$ & $\begin{array}{r}11.640^{* *} \\
\text { * } \\
(0.377)\end{array}$ & $\begin{array}{r}10.862^{\star * *} \\
\text { * } \\
(0.321)\end{array}$ & $\begin{array}{r}12.500^{* *} \\
(0.433)\end{array}$ & $\begin{array}{r}12.874^{\star *} \\
\text { * } \\
(0.024)\end{array}$ & $\begin{array}{r}11.087^{* *} \\
\text { * } \\
(0.212)\end{array}$ & $\begin{array}{r}11.078^{\star \star} \\
\text { * } \\
(0.691)\end{array}$ & $\begin{array}{r}11.159^{* *} \\
\text { * } \\
(0.303)\end{array}$ & $\begin{array}{r}11.359^{* *} \\
(0.373)\end{array}$ \\
\hline $\begin{array}{l}\text { Number of } \\
\text { observations }\end{array}$ & 6,865 & 6,798 & 5,004 & 1,794 & 6,865 & 6,798 & 1,604 & 3,753 & 1,441 & 6,865 & 6,798 & 789 & 4,218 & 1,791 \\
\hline R-Squared & 0.167 & 0.426 & 0.406 & 0.535 & 0.168 & 0.426 & 0.474 & 0.419 & 0.548 & 0.167 & 0.426 & 0.540 & 0.415 & 0.515 \\
\hline $\begin{array}{l}\text { Adjusted R- } \\
\text { Squared }\end{array}$ & 0.154 & 0.414 & 0.390 & 0.502 & 0.155 & 0.414 & 0.431 & 0.398 & 0.505 & 0.154 & 0.415 & 0.462 & 0.397 & 0.478 \\
\hline
\end{tabular}

Note: UNPS 2010-11; The estimates are weighted in accordance with the complex survey design; $\S$ denotes dummy variable;

District fixed effects; statistical significance is indicated as follows: ${ }^{* *} p<0.01,{ }^{* *} p<0.05$, *

$p<0.1$ 
Table 3: Sensitivity Analysis - Base OLS Pooled Sample Regression Results on Gender Differences in Agricultural Productivity - Different Crops

Dependent Variable: Log[Plot Gross Annual Value of Output per Acre] - Uganda 2010-11

\begin{tabular}{rccccc}
\hline & \multicolumn{6}{c}{ Household Head } \\
\hline & maize & beans & cassava & $\begin{array}{c}\text { banana } \\
\text { food }\end{array}$ & $\begin{array}{r}\text { sweet } \\
\text { potato }\end{array}$ \\
\hline Only Female $\S$ & -0.080 & 0.053 & -0.039 & 0.122 & -0.093 \\
& $(0.123)$ & $(0.110)$ & $(0.118)$ & $(0.154)$ & $(0.124)$ \\
\hline Number of observations & 1,856 & 1,902 & 1,436 & 1,153 & 1,276 \\
R-Squared & 0.304 & 0.333 & 0.251 & 0.352 & 0.255 \\
Adjusted R-Squared & 0.254 & 0.288 & 0.184 & 0.288 & 0.178
\end{tabular}

\begin{tabular}{rcccc}
\hline \multicolumn{5}{c}{ Plot Holder } \\
\hline maize & beans & cassava & $\begin{array}{c}\text { banana } \\
\text { food }\end{array}$ & $\begin{array}{c}\text { sweet } \\
\text { potato }\end{array}$ \\
\hline 0.049 & -0.060 & 0.036 & 0.081 & $-\mathbf{0 . 2 2 4} 4^{\star *}$ \\
$(0.110)$ & $(0.095)$ & $(0.111)$ & $(0.118)$ & $\mathbf{( 0 . 1 1 1 )}$ \\
\hline 1,856 & 1,902 & 1,436 & 1,153 & 1,276 \\
0.304 & 0.333 & 0.251 & 0.352 & 0.257 \\
0.254 & 0.289 & 0.183 & 0.289 & 0.180 \\
\hline
\end{tabular}

\begin{tabular}{ccccc}
\hline \multicolumn{5}{c}{ Plot Manager } \\
\hline maize & beans & cassava & $\begin{array}{c}\text { banana } \\
\text { food }\end{array}$ & $\begin{array}{c}\text { sweet } \\
\text { potato }\end{array}$ \\
\hline 0.037 & -0.053 & -0.061 & 0.086 & $-\mathbf{0 . 2 1 1 ^ { \star * }}$ \\
$(0.097)$ & $(0.087)$ & $(0.107)$ & $(0.108)$ & $\mathbf{( 0 . 0 8 8 )}$ \\
\hline 1,856 & 1,902 & 1,436 & 1,153 & 1,276 \\
0.304 & 0.334 & 0.248 & 0.352 & 0.260 \\
0.254 & 0.290 & 0.179 & 0.289 & 0.183 \\
\hline
\end{tabular}

Note: UNPS 2010-11; The estimates are weighted in accordance with the complex survey design;

District fixed effects; statistical significance is indicated as follows: ${ }^{* * *} p<0.01,{ }^{* *} p<0.05,{ }^{*} p<0.1$ 
Table 4: Sensitivity Analysis - Base OLS Pooled Sample Regression - Step Wise

Dependent Variable: Log[Plot Gross Annual Value of Output per Acre] - Uganda 2010-11

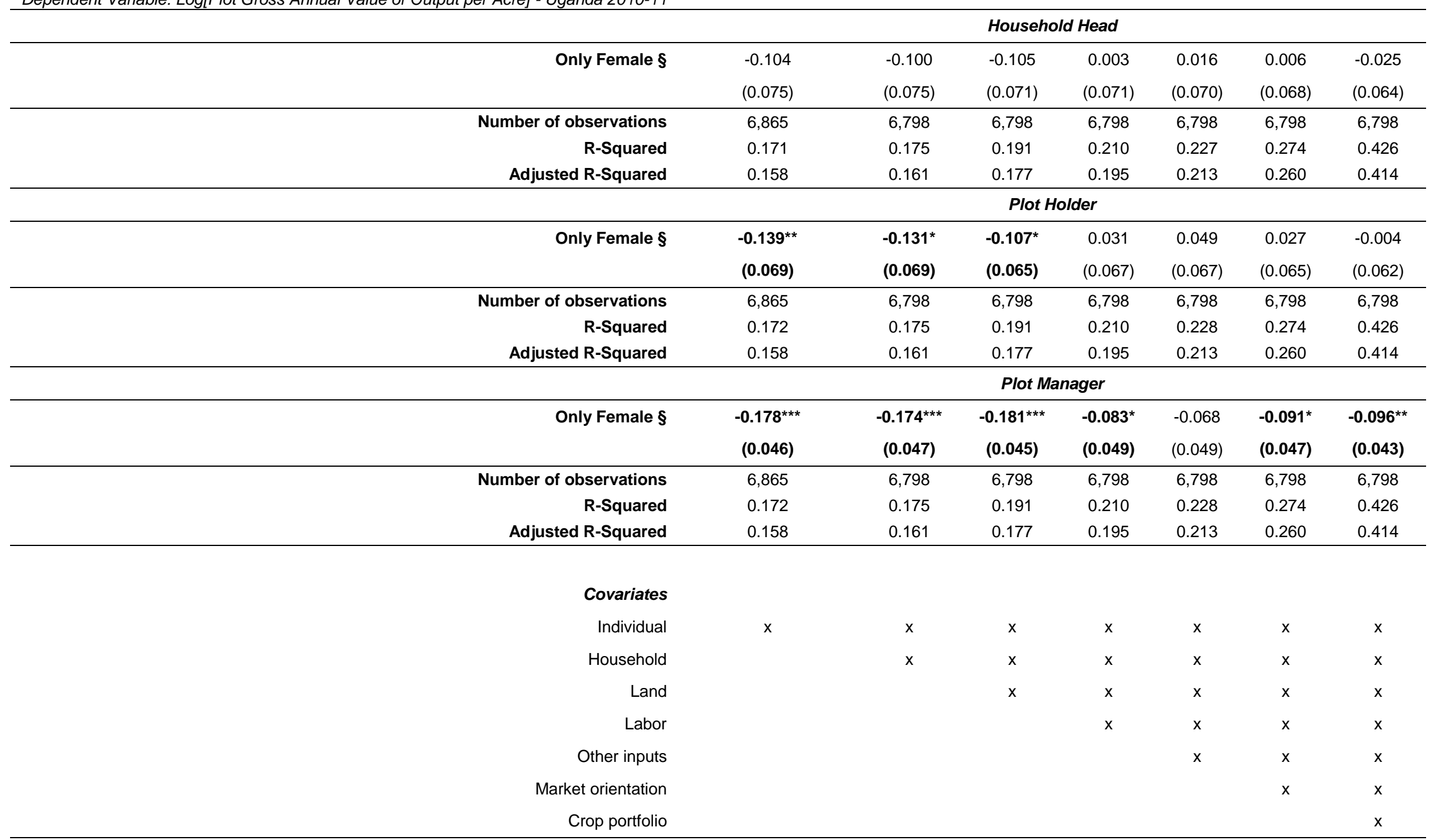

Note: UNPS 2010-11; The estimates are weighted in accordance with the complex survey design; $\S$ denotes dummy variable;

District fixed effects; statistical significance is indicated as follows ${ }^{* \star *} p<0.01,{ }^{* \star} p<0.05,{ }^{*} p<0.1$ 


\begin{tabular}{|c|c|c|c|c|c|c|}
\hline & \multicolumn{2}{|c|}{ Household Head } & \multicolumn{2}{|c|}{ Holders } & \multicolumn{2}{|c|}{ Managers } \\
\hline & $\begin{array}{l}\text { FHH } \\
\text { Plots }\end{array}$ & MHH Plots & Only female & Only male & Only female & Only male \\
\hline & (1) & (2) & (3) & (4) & (5) & (6) \\
\hline \multirow[t]{2}{*}{ Age } & -0.009 & $0.018^{\star}$ & $-0.031^{\star \star}$ & $0.021^{\star \star}$ & 0.012 & $0.026^{\star \star}$ \\
\hline & $(0.015)$ & $(0.010)$ & $(0.015)$ & $(0.010)$ & $(0.014)$ & (0.011) \\
\hline \multirow[t]{2}{*}{ Age squared/100 } & 0.000 & $-0.017^{\star}$ & 0.018 & $-0.020^{\star *}$ & -0.013 & $-0.029^{\star \star \star}$ \\
\hline & $(0.014)$ & $(0.009)$ & $(0.014)$ & (0.009) & $(0.013)$ & (0.011) \\
\hline \multirow[t]{2}{*}{ Polygamously married } & 0.142 & $0.106^{\star}$ & 0.168 & $0.106^{\star}$ & 0.014 & -0.037 \\
\hline & $(0.159)$ & $(0.060)$ & $(0.138)$ & $(0.060)$ & $(0.123)$ & $(0.164)$ \\
\hline \multirow[t]{2}{*}{ Number of individuals age 15 and older } & $0.071^{\star \star}$ & 0.001 & $0.071^{\star \star}$ & 0.002 & $0.063^{\star \star}$ & 0.009 \\
\hline & $(0.031)$ & $(0.020)$ & $(0.028)$ & $(0.020)$ & $(0.025)$ & $(0.022)$ \\
\hline \multirow[t]{2}{*}{ Child dependency ratio, $10 \mathrm{yrs}$ cut off } & $-0.395^{\star \star}$ & -0.138 & $-0.323^{\star}$ & -0.220 & -0.186 & -0.178 \\
\hline & $(0.197)$ & $(0.150)$ & $(0.185)$ & $(0.154)$ & $(0.178)$ & $(0.165)$ \\
\hline \multirow[t]{2}{*}{ PCA Wealth Index } & 0.013 & $0.042^{\star \star}$ & -0.005 & $0.049^{\star *}$ & -0.012 & $0.062^{\star \star \star}$ \\
\hline & $(0.030)$ & $(0.021)$ & $(0.038)$ & $(0.020)$ & $(0.026)$ & $(0.021)$ \\
\hline \multirow[t]{2}{*}{ Does the household owns the parcel or just have access to it } & 0.209 & -0.088 & $0.303^{\star \star \star}$ & -0.148 & $0.233^{\star \star}$ & -0.149 \\
\hline & $(0.131)$ & $(0.088)$ & $(0.116)$ & $(0.089)$ & $(0.111)$ & $(0.091)$ \\
\hline \multirow[t]{2}{*}{ Log plot size } & $-0.379^{\star \star \star}$ & $-0.314^{\star \star \star}$ & $-0.371^{\star \star \star}$ & $-0.320^{\star \star \star}$ & $-0.366^{\star \star \star}$ & $-0.303^{\star \star \star}$ \\
\hline & $(0.043)$ & $(0.029)$ & $(0.042)$ & $(0.029)$ & $(0.038)$ & $(0.030)$ \\
\hline \multirow[t]{2}{*}{ Did you hire any labor on this plot during any season } & 0.121 & 0.073 & 0.093 & 0.070 & $0.133^{\star}$ & 0.039 \\
\hline & $(0.080)$ & $(0.054)$ & $(0.081)$ & $(0.054)$ & $(0.073)$ & $(0.057)$ \\
\hline \multirow[t]{2}{*}{ Male adult family labour used on plot } & -0.038 & $0.389^{\star \star \star}$ & -0.019 & $0.412^{\star \star *}$ & 0.060 & $0.448^{\star * *}$ \\
\hline & $(0.075)$ & $(0.078)$ & $(0.070)$ & $(0.081)$ & $(0.065)$ & $(0.094)$ \\
\hline Female adult family labour used on plot & 0.131 & -0.037 & 0.024 & -0.015 & 0.126 & 0.081 \\
\hline
\end{tabular}




\begin{tabular}{|c|c|c|c|c|c|c|}
\hline & $(0.154)$ & $(0.121)$ & $(0.153)$ & $(0.123)$ & $(0.171)$ & $(0.120)$ \\
\hline \multirow[t]{2}{*}{ Child family labour used on plot } & $0.139^{*}$ & 0.053 & 0.096 & 0.071 & 0.104 & 0.070 \\
\hline & $(0.078)$ & $(0.056)$ & $(0.075)$ & $(0.056)$ & $(0.070)$ & $(0.057)$ \\
\hline \multirow[t]{2}{*}{ Use of organic or inorganic fertilizer } & -0.098 & 0.074 & -0.067 & 0.060 & -0.086 & 0.121 \\
\hline & $(0.128)$ & $(0.071)$ & $(0.128)$ & $(0.072)$ & $(0.105)$ & $(0.075)$ \\
\hline \multirow[t]{2}{*}{ Pesticides were used at least in one season } & 0.174 & $0.172^{\star \star}$ & $0.333^{\star}$ & $0.170^{\star \star}$ & $0.252^{\star}$ & $0.166^{* \star}$ \\
\hline & $(0.162)$ & $(0.079)$ & $(0.178)$ & $(0.079)$ & $(0.145)$ & $(0.082)$ \\
\hline \multirow{2}{*}{ A member of the household has received TA of any source } & 0.095 & 0.091 & 0.078 & $0.091^{*}$ & 0.020 & $0.111^{* *}$ \\
\hline & $(0.103)$ & $(0.056)$ & $(0.100)$ & $(0.055)$ & $(0.086)$ & $(0.056)$ \\
\hline \multirow[t]{2}{*}{ Share of plot cultivating staple crops } & $-0.820^{\star \star \star}$ & $-0.924^{\star \star \star}$ & $-0.813^{\star \star \star}$ & $-0.925^{\star \star \star}$ & $-0.871^{\star \star \star}$ & $-0.927^{\star \star \star}$ \\
\hline & $(0.124)$ & $(0.080)$ & $(0.133)$ & $(0.079)$ & $(0.118)$ & $(0.082)$ \\
\hline \multirow[t]{2}{*}{ Production is marketed } & $0.559^{\star \star \star}$ & $0.475^{\star \star \star}$ & $0.606^{\star \star \star}$ & $0.462^{\star \star \star}$ & $0.562^{\star \star \star}$ & $0.460^{\star \star \star}$ \\
\hline & $(0.084)$ & $(0.056)$ & $(0.083)$ & $(0.057)$ & $(0.074)$ & $(0.059)$ \\
\hline \multirow[t]{2}{*}{ _cons } & $11.776^{\star \star \star}$ & $11.551^{* \star *}$ & $12.322^{\star \star \star}$ & $11.538^{\star * *}$ & $11.032^{\star \star *}$ & $11.291^{\star \star \star}$ \\
\hline & $(0.483)$ & $(0.325)$ & $(0.461)$ & $(0.329)$ & $(0.430)$ & $(0.335)$ \\
\hline Number of observations & 1,391 & 4,035 & 1,478 & 3,948 & 1,899 & 3,527 \\
\hline R-Squared & 0.538 & 0.401 & 0.529 & 0.406 & 0.486 & 0.417 \\
\hline Adjusted R-Squared & 0.494 & 0.381 & 0.486 & 0.386 & 0.449 & 0.395 \\
\hline
\end{tabular}

Note: UNPS 2010-11; Selected results; Lags in fertilizer, pesticides, hired labor, intercropping;

The estimates are weighted in accordance with the complex survey design; $\S$ denotes dummy variable;

District fixed effects; statistical significance is indicated as follows ${ }^{* \star *} p<0.01,{ }^{* *} p<0.05,{ }^{*} p<0.1$ 
Table 6: Descriptive statistics of household descriptors over time

\begin{tabular}{|c|c|c|}
\hline & 2010-11 & 2011-12 \\
\hline Number of observations & 2,757 & 2,757 \\
\hline \multicolumn{3}{|l|}{ Household head characteristics } \\
\hline Household head is female & 0.261 & 0.27 \\
\hline Age & 48.165 & $49.021^{\star *}$ \\
\hline Years of schooling & 4.784 & $4.532^{\star \star}$ \\
\hline Monogamously married & 0.564 & 0.554 \\
\hline Polygamously married & 0.203 & 0.206 \\
\hline Divorced & 0.073 & 0.084 \\
\hline Widowed & 0.153 & 0.150 \\
\hline Single & 0.007 & 0.007 \\
\hline \multicolumn{3}{|l|}{ Household characteristics } \\
\hline Number of individuals age 15 and older & 3.017 & 3.002 \\
\hline Child dependency ratio, $10 y$ rs cut off & 0.308 & $0.290^{\star \star \star}$ \\
\hline Labor income & 0.314 & $0.290^{*}$ \\
\hline Household Wealth Index & 0.060 & 0.054 \\
\hline
\end{tabular}

Note: UNPS 2010-11, 2011-12;

statistical significance is indicated as follows ${ }^{* * *} p<0.01,{ }^{* *} p<0.05,{ }^{*} p<0.1$ 
Table 7: Base OLS Regression Results on Gender Differences in Agricultural Productivity with Time Fixed Effects

Dependent Variable: Log[Plot Gross Annual Value of Output per Acre] - Uganda (2010-11/2011-12)

\begin{tabular}{|c|c|c|c|c|c|c|c|}
\hline & \multicolumn{3}{|c|}{$\begin{array}{l}\text { Household Head } \\
\text { Year \& District FE }\end{array}$} & \multicolumn{4}{|c|}{$\begin{array}{c}\text { Plot Holder } \\
\text { Year \& District FE }\end{array}$} \\
\hline & $\begin{array}{l}\text { Pooled } \\
\text { Sample }\end{array}$ & MHH Plots & FHH Plots & $\begin{array}{l}\text { Pooled } \\
\text { Sample }\end{array}$ & Male plots & Joint plots & Female plots \\
\hline & (1) & (2) & (3) & (4) & (5) & (6) & (7) \\
\hline year $=1$ & -0.052 & -0.040 & $-0.268^{\star}$ & -0.061 & -0.258 & 0.035 & $-0.426^{\star \star}$ \\
\hline & $(0.073)$ & $(0.084)$ & $(0.149)$ & $(0.072)$ & $(0.272)$ & $(0.111)$ & $(0.189)$ \\
\hline Only Female § & 0.037 & & & 0.007 & & & \\
\hline & $(0.209)$ & & & $(0.102)$ & & & \\
\hline \multicolumn{8}{|l|}{ Individual and Household Characteristics } \\
\hline \multirow[t]{2}{*}{ Age (Years) } & $-0.018^{\star}$ & -0.003 & $-0.037^{\star}$ & $-0.012^{\star \star}$ & 0.042 & $-0.021^{* *}$ & $-0.037^{\star \star \star}$ \\
\hline & $(0.009)$ & $(0.016)$ & $(0.022)$ & $(0.006)$ & $(0.038)$ & $(0.011)$ & $(0.010)$ \\
\hline \multirow[t]{2}{*}{ Age squared/100 } & -0.000 & -0.000 & $0.000^{\star \star}$ & 0.000 & 0.000 & -0.000 & $0.000^{\star \star}$ \\
\hline & $(0.000)$ & $(0.000)$ & $(0.000)$ & $(0.000)$ & $(0.000)$ & $(0.000)$ & $(0.000)$ \\
\hline \multirow[t]{2}{*}{ Years of schooling } & -0.006 & -0.012 & -0.036 & -0.002 & 0.032 & 0.003 & -0.004 \\
\hline & $(0.012)$ & $(0.015)$ & $(0.028)$ & $(0.012)$ & $(0.039)$ & $(0.019)$ & $(0.036)$ \\
\hline \multirow[t]{2}{*}{ Years of schooling squared/100 } & 0.001 & 0.001 & 0.002 & 0.001 & 0.003 & 0.001 & 0.004 \\
\hline & $(0.001)$ & $(0.001)$ & $(0.002)$ & $(0.001)$ & $(0.004)$ & $(0.001)$ & $(0.003)$ \\
\hline \multirow[t]{2}{*}{ Polygamous married $\S$} & 0.119 & 0.246 & 0.040 & 0.227 & 0.408 & 0.992 & 0.399 \\
\hline & $(0.290)$ & $(0.480)$ & $(0.247)$ & $(0.288)$ & $(0.687)$ & $(0.714)$ & $(0.556)$ \\
\hline \multirow[t]{2}{*}{ Unmarried (Divorced; Widowed; Single) § } & 0.256 & $0.562^{\star \star}$ & 0.473 & $0.519^{\star \star *}$ & $1.588^{\star \star}$ & 0.197 & 0.855 \\
\hline & $(0.222)$ & $(0.226)$ & $(0.420)$ & $(0.191)$ & $(0.681)$ & $(0.236)$ & $(0.583)$ \\
\hline \multirow[t]{2}{*}{ Household members age $15+$} & 0.033 & 0.053 & 0.003 & 0.033 & 0.086 & 0.053 & 0.070 \\
\hline & $(0.029)$ & $(0.035)$ & $(0.057)$ & $(0.028)$ & $(0.169)$ & $(0.040)$ & $(0.093)$ \\
\hline Child dependency ratio (10yrs cut-off) & -0.400 & -0.474 & -0.457 & -0.400 & -0.498 & -0.274 & 0.102 \\
\hline
\end{tabular}




\begin{tabular}{|c|c|c|c|c|c|c|c|}
\hline \multirow[b]{3}{*}{ Participation non-agr wage labor $\S$} & \multirow{2}{*}{$(0.272)$} & \multirow[b]{2}{*}{$(0.324)$} & \multirow[b]{2}{*}{$(0.455)$} & \multirow[b]{2}{*}{$(0.271)$} & \multirow[b]{2}{*}{$(1.098)$} & \multirow[b]{2}{*}{$(0.486)$} & \multirow[b]{2}{*}{$(0.505)$} \\
\hline & & & & & & & \\
\hline & $0.116^{\star \star}$ & $0.131^{\star \star}$ & 0.056 & $0.095^{\star}$ & 0.144 & 0.105 & $-0.292^{\star \star}$ \\
\hline \multirow{3}{*}{ PCA Wealth Asset Index } & $(0.056)$ & $(0.066)$ & $(0.105)$ & $(0.056)$ & $(0.196)$ & $(0.085)$ & $(0.143)$ \\
\hline & 0.014 & 0.000 & 0.060 & 0.015 & 0.030 & -0.000 & 0.076 \\
\hline & $(0.021)$ & $(0.023)$ & $(0.048)$ & $(0.021)$ & $(0.058)$ & $(0.028)$ & $(0.047)$ \\
\hline \multicolumn{8}{|l|}{ Plot Characteristics } \\
\hline \multirow[t]{2}{*}{ Plot owned § } & -0.046 & -0.049 & -0.110 & -0.091 & 0.186 & -0.154 & -0.415 \\
\hline & $(0.161)$ & $(0.189)$ & $(0.312)$ & $(0.165)$ & $(0.366)$ & $(0.194)$ & $(0.359)$ \\
\hline \multirow[t]{2}{*}{ Log Plot Size } & $-0.475^{\star \star \star}$ & $-0.467^{\star \star \star}$ & $-0.644^{\star \star \star}$ & $-0.480^{\star \star \star}$ & $-0.361^{\star \star \star}$ & $-0.460^{\star \star \star}$ & $-0.701^{\star \star \star}$ \\
\hline & $(0.033)$ & $(0.037)$ & $(0.065)$ & $(0.034)$ & $(0.109)$ & $(0.049)$ & $(0.075)$ \\
\hline \multirow[t]{2}{*}{ Good quality of soil and flat $\S$} & 0.059 & 0.168 & -0.410 & 0.020 & 0.632 & -0.262 & -0.781 \\
\hline & $(0.262)$ & $(0.336)$ & $(0.450)$ & $(0.265)$ & (0.953) & $(0.444)$ & $(0.475)$ \\
\hline \multirow[t]{2}{*}{ Main water source is irrigation $\S$} & -0.112 & -0.361 & $0.466^{\star}$ & 0.068 & $-1.164^{\star \star \star}$ & 0.123 & 0.241 \\
\hline & $(0.251)$ & $(0.373)$ & $(0.256)$ & $(0.182)$ & (0.345) & $(0.289)$ & $(0.306)$ \\
\hline \multirow[t]{2}{*}{ Distance from holding $>30 \mathrm{~min} \S$} & 0.024 & 0.132 & $-0.363^{\star \star}$ & 0.029 & 0.090 & 0.095 & -0.244 \\
\hline & $(0.099)$ & $(0.120)$ & $(0.169)$ & $(0.100)$ & $(0.295)$ & $(0.174)$ & $(0.244)$ \\
\hline \multicolumn{8}{|l|}{ Labor and Inputs } \\
\hline \multirow{2}{*}{ Hired labor $\S$} & $0.173^{\star \star *}$ & $0.237^{\star \star \star}$ & 0.001 & $0.202^{\star \star \star}$ & $0.334^{\star \star}$ & $0.220^{\star \star}$ & 0.144 \\
\hline & $(0.062)$ & $(0.073)$ & $(0.106)$ & $(0.058)$ & $(0.156)$ & $(0.090)$ & $(0.121)$ \\
\hline \multirow[t]{2}{*}{ Male adult family labour used on plot $\S$} & $0.167^{\star}$ & 0.157 & 0.155 & $0.173^{\star \star}$ & 0.417 & 0.054 & 0.105 \\
\hline & $(0.086)$ & $(0.114)$ & $(0.128)$ & $(0.085)$ & $(0.282)$ & $(0.127)$ & (0.169) \\
\hline \multirow[t]{2}{*}{ Female adult family labour used on plot $\S$} & $0.178^{\star \star}$ & 0.101 & $0.560^{\star \star *}$ & $0.203^{\star \star}$ & $0.548^{\star}$ & $0.316^{\star \star}$ & 0.310 \\
\hline & $(0.087)$ & $(0.099)$ & $(0.188)$ & $(0.087)$ & $(0.328)$ & $(0.153)$ & (0.282) \\
\hline \multirow[t]{2}{*}{ Child family labour used on plot $\S$} & 0.026 & -0.020 & 0.156 & 0.048 & $0.730^{\star \star \star}$ & -0.098 & $0.360^{\star *}$ \\
\hline & $(0.058)$ & $(0.070)$ & $(0.104)$ & $(0.059)$ & $(0.213)$ & $(0.083)$ & $(0.141)$ \\
\hline \multirow[t]{2}{*}{ Use of fertilizer $\S$} & $0.196^{\star \star}$ & $0.179^{*}$ & 0.183 & $0.174^{\star \star}$ & -0.039 & 0.234 & 0.273 \\
\hline & $(0.090)$ & $(0.106)$ & $(0.160)$ & $(0.086)$ & $(0.226)$ & $(0.159)$ & $(0.176)$ \\
\hline \multirow[t]{2}{*}{ Use of pesticides $\S$} & $0.196^{\star *}$ & $0.224^{\star \star}$ & 0.265 & $0.204^{\star \star}$ & 0.099 & $0.352^{\star \star}$ & 0.264 \\
\hline & $(0.092)$ & $(0.103)$ & $(0.267)$ & $(0.090)$ & $(0.292)$ & $(0.150)$ & $(0.358)$ \\
\hline
\end{tabular}




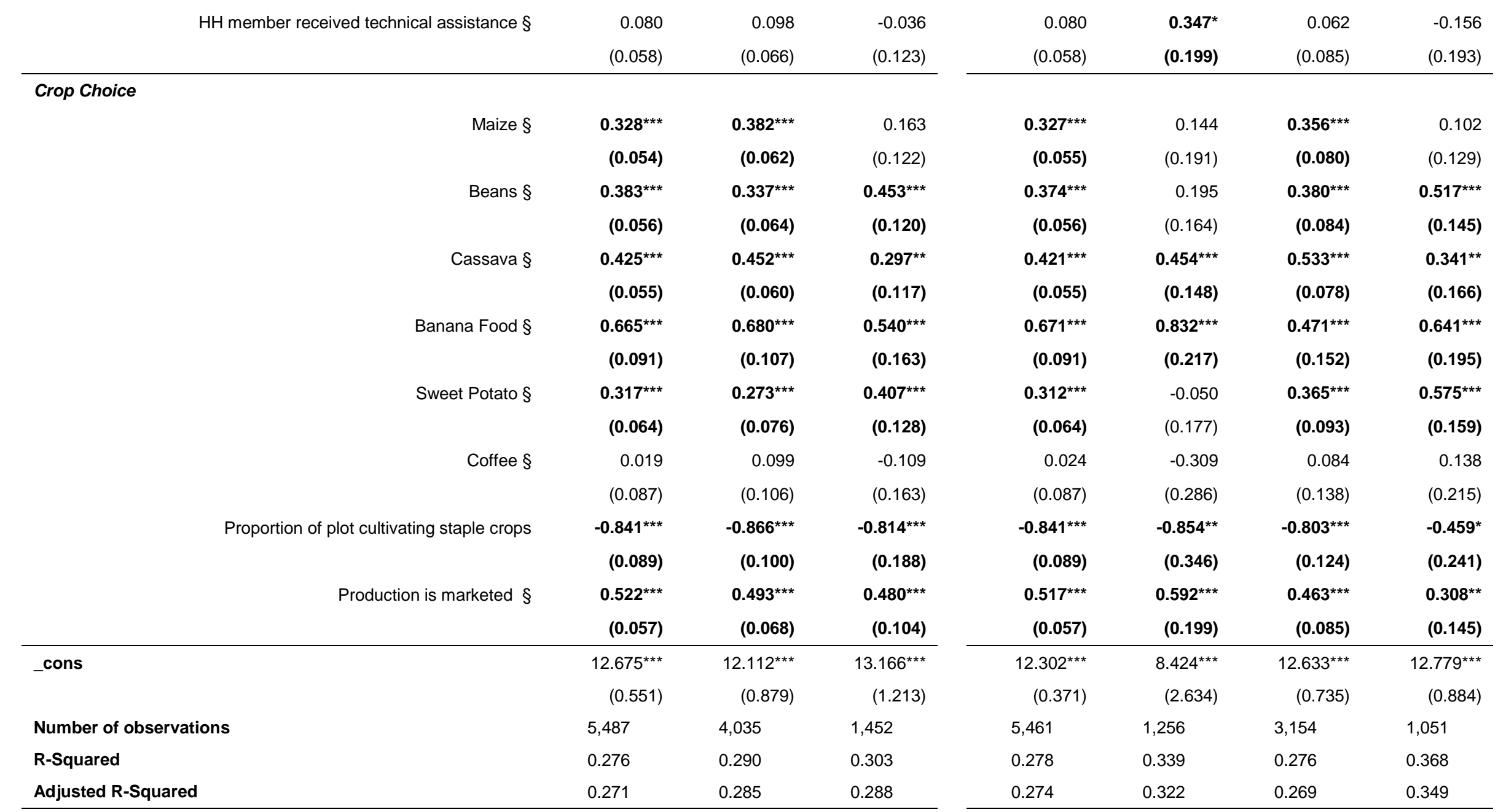

Note: UNPS 2010-11 and UNPS 2011-12; The estimates are weighted in accordance with the complex survey design;

Time fixed effects; statistical significance is indicated as follows ${ }^{* * *} p<0.01,{ }^{* *} p<0.05,{ }^{*} p<0.1$

$\S$ denotes dummy variable; 
Table 8: Decomposition of the Gender Differential in Agricultural Productivity in Uganda (2010-11)

Dependent Variable: Log[Plot Gross Annual Value of Output per Acre]

\section{A. Mean Gender Differential}

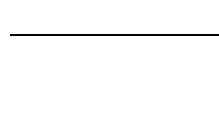

Head

$12.88^{* \star *}$
$(0.0228)$

Mean FHH

\begin{tabular}{|c|c|c|c|c|c|c|}
\hline \multirow[b]{2}{*}{ Mean Gender Differential } & $\begin{array}{l}12.70^{\star * *} \\
(0.0415)\end{array}$ & $\begin{array}{r}\text { Mean Female } \\
\text { Plot }\end{array}$ & $\begin{array}{r}12.730^{* * *} \\
(0.045)\end{array}$ & $\begin{array}{l}12.73^{\star \star *} \\
(0.0448)\end{array}$ & $\begin{array}{r}12.769^{* * *} \\
(0.040)\end{array}$ & $\begin{array}{l}12.77^{\star * *} \\
(0.0399)\end{array}$ \\
\hline & $\begin{array}{l}0.177^{\star \star \star} \\
(0.0474)\end{array}$ & $\begin{array}{l}\text { Mean Gender } \\
\text { Differential }\end{array}$ & $\begin{array}{l}0.202^{\star \star \star} \\
(0.059)\end{array}$ & $\begin{array}{l}0.101^{*} \\
(0.053)\end{array}$ & $\begin{array}{l}0.200^{\star \star \star} \\
(0.072)\end{array}$ & $\begin{array}{r}0.0657 \\
(0.0471)\end{array}$ \\
\hline \multicolumn{7}{|l|}{ B. Aggregate Decomposition } \\
\hline Endowment Effect & $\begin{array}{r}0.102 \\
(0.0533)\end{array}$ & $\begin{array}{r}\text { Endowment } \\
\text { Effect }\end{array}$ & $\begin{array}{r}0.133 \\
(0.0694)\end{array}$ & $\begin{array}{r}0.0968 \\
(0.0570)\end{array}$ & $\begin{array}{r}0.115 \\
(0.0728)\end{array}$ & $\begin{array}{r}0.0419 \\
(0.0440)\end{array}$ \\
\hline Share of gender differential & $57.6 \%$ & $\begin{array}{r}\text { Share of } \\
\text { gender } \\
\text { differential }\end{array}$ & $65.7 \%$ & $95.7 \%$ & $57.5 \%$ & $63.8 \%$ \\
\hline MHH Structural Advantage & $\begin{array}{l}2.25 e-15 \\
(0.00334)\end{array}$ & $\begin{array}{r}\text { Male } \\
\text { Structural } \\
\text { Advantage }\end{array}$ & $\begin{array}{r}2.22 \mathrm{e}-16 \\
(0.0121)\end{array}$ & $\begin{array}{l}-1.17 e-15 \\
(0.00450)\end{array}$ & $\begin{array}{l}3.44 \mathrm{e}-15 \\
(0.0238)\end{array}$ & $\begin{array}{l}-4.33 e-15 \\
(0.00415)\end{array}$ \\
\hline share of gender differential & $0.0 \%$ & $\begin{array}{r}\text { share of } \\
\text { gender } \\
\text { differential }\end{array}$ & $0.0 \%$ & $0.0 \%$ & $0.0 \%$ & $0.0 \%$ \\
\hline \multirow[t]{2}{*}{ FHH Structural Disadvantage } & 0.0750 & $\begin{array}{r}\text { Female } \\
\text { Structural } \\
\text { Disadvantage }\end{array}$ & 0.0690 & 0.00439 & 0.0848 & 0.0239 \\
\hline & $(0.0515)$ & & $(0.0641)$ & $(0.0542)$ & $(0.0668)$ & $(0.0420)$ \\
\hline Share of gender differential & $42.4 \%$ & $\begin{array}{r}\text { Share of } \\
\text { gender } \\
\text { differential }\end{array}$ & $34.1 \%$ & $4.3 \%$ & $42.4 \%$ & $36.4 \%$ \\
\hline \# obs. & 6798 & & 3045 & 5194 & 2580 & 6009 \\
\hline
\end{tabular}

Note: UNPS 2010-11; The estimates are weighted in accordance with the complex survey design; district fixed effects statistical significance is indicated as follows ${ }^{* * *} p<0.01,{ }^{* *} p<0.05,{ }^{*} p<0.1$ 